\title{
Physical Metallurgy of Modern Creep-Resistant Steel for Steam Power Plants: Microstructure and Phase Transformations
}

\author{
V. C. Igwemezie, ${ }^{1,2}$ C. C. Ugwuegbu, ${ }^{2}$ and U. Mark ${ }^{2}$ \\ ${ }^{1}$ Renewable Energy Marine Structures Centre for Doctoral Training (REMS CDT), Cranfield University, Cranfield, \\ Bedfordshire MK43 0AL, UK \\ ${ }^{2}$ Department of Materials \& Metallurgical Engineering, Federal University of Technology Owerri, Ihiagwa, Nigeria \\ Correspondence should be addressed to V. C. Igwemezie; victor.igwemezie@cranfield.ac.uk
}

Received 26 June 2016; Accepted 11 October 2016

Academic Editor: Sunghak Lee

Copyright (c) 2016 V. C. Igwemezie et al. This is an open access article distributed under the Creative Commons Attribution License, which permits unrestricted use, distribution, and reproduction in any medium, provided the original work is properly cited.

\begin{abstract}
The fact that the microstructure of steel depends on its composition and the heat treatment given to it has been heavily exploited in the design of steel for power plant applications. To obtain a steel that can function at the higher temperature where power plants operate without failure for extended life, heat treatment is needed to produce fine and highly stable dispersion of carbides, nitrides, and intermetallic compounds in the microstructure of the material. A significant contribution also comes from solid solution strengthening by substitutional solutes. We review here various types of phases, microstructures, functions, and interacting effects of the various alloying elements in the design of steel for modern power plant application.
\end{abstract}

\section{Dimensions of Steel}

The critical role that steel has played in the construction of our society is largely due to its superior adaptation to the wide ranges of mechanical requirements. The strength and toughness of steel can vary with changes in its microstructure, that is, the size and shape of grains and the detailed arrangement of the atoms [1].

There are behaviours of iron which are unseen from ordinary view but ultimately affect their physical behaviour. The macroscopic shape of steel crystal depends on the environment, processing, and many other factors determined mostly by the fact that a piece of steel is generally polycrystalline and is filled completely with millions of one or more kinds of crystals. The fact that a piece of steel contains varieties of crystals is frequently not apparent to many design engineers, making them treat the metal as a continuum, especially in modelling approaches.

The electrons form the bonds between atoms. The strength of these bonds is a major factor which affects the nature and properties of materials. Another consideration is that microstructure of steel by nature is imperfect. In practice, it is found that equilibrium in engineering steel demands that crystals should be imperfect or away from equilibrium.
Steels may not be very useful as they are presently without certain defects. There is always an equilibrium concentration of point defects and more significant are the nonequilibrium, unintended defects introduced in the process of manufacture [15].

In the design of steel for power plant or for high temperature application there are challenging engineering requirements for the materials engineer. The summary of these requirements is as follows [6]:

(1) High creep strength at high temperature

(2) High toughness and resistance to embrittlement

(3) Resistance to steam oxidation and corrosion

(4) Ease of fabrication and weldability

Not all steels are candidates for high temperature application. Study has shown that austenitic steels have higher coefficient of thermal expansion and low conductivity than ferritic steels. In other words, ferrite has much smaller thermal expansion coefficient and high thermal conductivity than austenite, as shown in Table 1.

When considered for elevated temperature service, materials with large thermal expansivities become susceptible to thermal fatigue, especially in thick sections of the kind 
TABLE 1: Comparison of the coefficient of thermal expansion (CTE) and thermal conductivity for ferritic and austenitic steel at $100^{\circ} \mathrm{C}$. The compositions (wt\%) of the steels are also given $[2,3]$.

(a)

\begin{tabular}{lcr}
\hline Steel & $\mathrm{CTE} / \mu \mathrm{m}^{-1} \mathrm{~K}^{-1}$ & Thermal conductivity $/ \mathrm{Wm}^{-1} \mathrm{~K}^{-1}$ \\
\hline Ferritic & 9.9 & 24.9 \\
Austenitic & 17.3 & 16.3 \\
\hline
\end{tabular}

(b)

\begin{tabular}{lcccccccc}
\hline Steel & AISI type & $\mathrm{C}$ & $\mathrm{Mn}$ & $\mathrm{P}$ & $\mathrm{S}$ & $\mathrm{Si}$ & $\mathrm{Cr}$ & $\mathrm{Ni}$ \\
\hline Ferritic & 403 & 0.15 & 1.00 & 0.040 & 0.03 & 0.50 & $11.5-13.0$ & - \\
Austenitic & 305 & 0.12 & 2.00 & 0.045 & 0.03 & 1.00 & $17-19$ & $10.5-13.0$ \\
\hline
\end{tabular}

frequently employed in power generation. This becomes a major problem due to the fact that steam turbines are often turned off and on during their service life. This thermal cycling can cause fatigue in austenitic steels. This has been the main reason why austenitic steels in spite of their superior creep strength are rejected in favour of ferritic steels for the construction of power plant [6]. Martensitic steels have smaller thermal expansion and larger thermal conductivity than austenitic steels and $\mathrm{Ni}$ base superalloys and are now offering highest potential to designing thick section steels for power plant application.

In the development of modern steam power plants, the goal is centred around increasing the steam parameters from the current optimum of about $620^{\circ} \mathrm{C}$ at $28 \mathrm{MPa}$ up to $700^{\circ} \mathrm{C}$ at $35 \mathrm{MPa}$ in order to improve efficiency and thereby reduce $\mathrm{CO}_{2}$ emission [19]. Further advanced steam conditions of $700^{\circ} \mathrm{C}$ and above have been already initiated to gain net efficiency higher than $50 \%$ at Thermie AD700 project in Europe and at DOE vision 21 project [13, 20, 21]. In the light of available knowledge so far, these steam conditions cannot be reached with ferritic-martensitic alloys, which are currently the state-of-the-art material for steam power plants $[19,22]$. Hence, these projects involve the replacement of 912Cr martensitic steels by Ni base superalloys for the highest temperature regimes. To minimize the requirement of expensive Ni base superalloys, as $\mathrm{Ni}$ superalloy is about ten times costlier than high temperature steels, 9-12Cr martensitic steels are planned to be used in the next highest temperature components of such very high temperature plants. Therefore, 9-12Cr martensitic steels are still strongly desired to expand the present temperature range up to $650^{\circ} \mathrm{C}$ and more. It should be noted that research is also going back to austenitic steels to see their possible use for $700^{\circ} \mathrm{C}$ USC plants in Japan.

\section{Phase Transformation in Creep Steel for Power Plant}

The general rule for determining if creep will occur in metals or not is $[23,24]$

$$
T>0.3-0.4\left(T_{M}\right)
$$

Pure iron has a melting temperature, $T_{M}$, of about $1536^{\circ} \mathrm{C}$ and the equation above suggests that pure iron would creep at temperature where traditional steam power plant operates, that is, in temperature range of $450-565^{\circ} \mathrm{C}$.

Since service temperature depends on the melting temperature of the steel, a direct approach to solving the creep problem is to use metals with high melting temperatures so that the temperature at which creep occurs is increased. An example of such metals is tungsten with $T_{M}$ of $3407^{\circ} \mathrm{C}$. In this case, creep becomes important above about $1363^{\circ} \mathrm{C}$ which is far above the aforementioned temperature range for power plants. This apparent advantage comes with considerable consequences. Firstly, W is several times more expensive than steel, which could make affordability of the power plant very unlikely for most countries. This cost implication and the attendant low demand will have a negative impact on the huge investment in the technology. Secondly, the oxide of tungsten $\left(\mathrm{WO}_{3}\right)$ sublimes and so forth is not considered as a practical solution. Another approach could be to use nickel-based superalloys. Study has shown that the creep rupture strength of the nickel-based superalloys is very good at high temperatures and they have a sufficiently low expansion coefficient. Unfortunately, they are about 6-10 times more expensive than low alloy steels, depending on the alloy composition and market prices of alloying elements. In addition, nickel-based superalloys are more expensive to weld and machine.

Almost all steels rely on the transformation between austenite and ferrite for obtaining the desired microstructure. When the high temperature $f c c$-phase austenite in steel decomposes to the less dense $b c c$-phase ferrite, a number of different microstructures and morphologies can form, which depend on the cooling rate, the presence of alloying elements, and the conditions and availability of lower energy nucleation sites for heterogeneous nucleation. The transformation temperature between austenite and ferrite can be greatly affected by the presence of solutes, such as $\mathrm{C}, \mathrm{Si}, \mathrm{Mn}, \mathrm{Ni}, \mathrm{Mo}, \mathrm{Cr}, \mathrm{W}$, $\mathrm{Ti}, \mathrm{Nb}$, and $\mathrm{V}$. For example, $0.8 \mathrm{wt} \%$ carbon lowers the second solid-state transformation temperature from $910^{\circ} \mathrm{C}$ to $723^{\circ} \mathrm{C}$.

The transformation temperature can also be altered by changing the cooling rate from elevated temperatures. A rapidly cooled steel transforms at a lower temperature and there is shorter amount of time available to accomplish the necessary changes in atomic positions before the material finally cools down to room temperature. The products of such transformation are metastable phases. The advantage of 
TABLE 2: Stored energy as function of microstructure, defined relative to microstructure for which stored energy is arbitrarily set to zero [adapted from [4]].

\begin{tabular}{|c|c|c|}
\hline Case & Microstructure & Stored energy, J/mol \\
\hline \multicolumn{3}{|c|}{$\begin{array}{l}\text { Phase mixture in } \\
\mathrm{Fe}-0.2 \mathrm{C}-1.5 \mathrm{Mn} \text { wt } \% \text { at } 27^{\circ} \mathrm{C}\end{array}$} \\
\hline 1 & Ferrite, graphite, and cementite & 0 \\
\hline 2 & Ferrite and cementite & 70 \\
\hline 3 & Paraequilibrium ferrite and paraequilibrium cementite & 385 \\
\hline 4 & Bainite and paraequilibrium cementite & 785 \\
\hline 5 & Martensite & 1214 \\
\hline \multicolumn{3}{|c|}{$\begin{array}{l}\text { Phase mixture in } \\
\mathrm{Fe}-0.1 \mathrm{C}-2.2 \mathrm{Cr}-1 \mathrm{Mn} w t \% \text { at } \\
600^{\circ} \mathrm{C}\end{array}$} \\
\hline 6 & Ferrite and paraequilibrium cementite $\rightarrow$ ferrite and $M_{2} X$ (e.g., when steel enters service) & 63 \\
\hline 7 & Ferrite and paraequilibrium cementite $\rightarrow$ ferrite and $\mathrm{M}_{23} \mathrm{C}_{6}$ (e.g., after long service time) & 0 \\
\hline
\end{tabular}

fast cooling is that the structural scale is reduced, which is advantageous in achieving greater strength and toughness [1].

To obtain a steel that can function at the higher temperature where power plants operate without failure for extended life, pure iron is alloyed with other elements such as $\mathrm{C}, \mathrm{Cr}, \mathrm{Ni}, \mathrm{Mn}, \mathrm{Mg}, \mathrm{W}, \mathrm{Ti}, \mathrm{V}, \mathrm{Mo}$, and $\mathrm{Nb}$ and then heat-treated to produce steel with required creep properties. Creep steels are able to survive for such long periods as 30 years because the operating temperature is only about half of the absolute melting temperature, making the migration of atoms very slow to cause any significant change in the steel microstructure.

In power plants, the longevity of iron alloys relies on the fact that the diffusivities are incredibly small $[4,25]$. Notwithstanding this, slow but significant changes are observed to occur over the long service life. Another consequence of the small diffusion coefficients is that the dominant creep mechanism is the climb of dislocations over obstacles with the help of thermal energy. The obstacles are mainly carbide particles which are dispersed throughout the microstructure [4].

Another reason why the changes that are expected over the years must occur at a slow rate is that the steels are generally tempered before they enter service, producing a very stable microstructure and relieving stresses. The stability can be discussed in terms of the free energy stored in the material, as illustrated in Table 2 [4].

The stored energy of the plain carbon steel, (Phase mixture in $\mathrm{Fe}-0.2 \mathrm{C}-1.5 \mathrm{Mn}$ wt $\%$ at $27^{\circ} \mathrm{C}$ ) is described relative to the equilibrium state which is a mixture of ferrite, graphite, and cementite without any defects. The phases in cases 1 and 2 involve the equilibrium partitioning of all elements so as to minimize free energy, that is, minimize the tendency to react further. In cases $3-5$, the substitutional solutes are frozen in their position.

It can be seen that bainite and martensite have higher stored energies relative to ferrite because of strain energy contributions and solute trapping. The term paraequilibrium means that the phase has the same ratio of iron to substitutional solute atoms as the parent phase from which it formed.
Cases 6 and 7 are for a classical power plant alloy, Fe-0.1C-2.2Cr-1Mo wt $\%$ at $600^{\circ} \mathrm{C}$. Here, the reduction in stored energy when the microstructure changes from $\mathrm{M}_{2} \mathrm{X}$ to $\mathrm{M}_{23} \mathrm{C}_{6}$ microstructure is very small. This means that this transformation will occur at a corresponding slow rate. In summary, the reaction rate of a transformation can be controlled by the available Gibbs free energy, also referred to as the driving force, and by the diffusivity of carbon.

\section{The Matrix Microstructure of Creep Steel}

The ability of power plant steels to resist creep deformation depends on the presence in the microstructure of fine and highly stable dispersion of carbides and intermetallic compounds which precipitate during tempering or during elevated temperature service [4]. The carbides interfere with the climb and glide of dislocations and retard the coarsening rate of the microstructure as a whole, for example, the size and shape of martensite or bainite plates. In other words, these particles not only interfere with the progress of dislocations but also stabilize the microstructure so that features such as lath boundaries change very slowly during long-term service at elevated temperatures [7]. A significant contribution also comes from solid solution strengthening by substitutional solutes. The solid solution strengthening component is found to become more important after prolonged service at elevated temperature, as the microstructural contribution to strengthening diminishes due to annealing effects.

The heat treatments given to the steels before service are usually so severe that the precipitates are in an overaged condition. The microstructures are therefore relatively stable before entering service, though further microstructural changes are inevitable given that service involves many decades at temperatures where substitutional atoms have significant mobility and this change is sometimes used to monitor remaining life of the steel components.

Majority of steels used in fossil power plants in the whole world are constructed from low alloy steels containing $\mathrm{Cr}$, $\mathrm{Mo}$, and $\mathrm{V}$ as the major alloying elements. The total alloy concentration is usually less than $5 \mathrm{wt} \%$ [4]. These include 
TABLE 3: Chemical compositions (wt\%) of some low-alloy creep-resistant steels for power plant construction.

\begin{tabular}{lccccccc}
\hline Designation & $\mathrm{C}$ & $\mathrm{Si}$ & $\mathrm{Mn}$ & $\mathrm{Ni}$ & $\mathrm{Mo}$ & $\mathrm{Cr}$ & - \\
\hline 1Cr0.5Mo & 0.15 & 0.25 & 0.50 & - & 0.60 & 0.95 & 0.30 \\
$0.25 \mathrm{CrMoV}$ & 0.15 & 0.25 & 0.50 & 0.05 & 0.50 & 0.25 \\
$0.5 \mathrm{Cr} 0.5 \mathrm{Mo} 0.25 \mathrm{~V}$ & 0.12 & 0.25 & 0.50 & - & 0.60 & 0.45 & 0.25 \\
CrMoV & 0.25 & 0.25 & 0.75 & 0.70 & 1.00 & 1.10 & 0.35 \\
$2.25 \mathrm{Cr}$ Mo & 0.15 & 0.25 & 0.50 & 0.10 & 1.00 & 2.30 & 0.00 \\
\hline
\end{tabular}

TABLE 4: Heat treatment conditions, matrix phase, and precipitates for steels of varying chromium content [5].

\begin{tabular}{lcccc}
\hline Steel & Water quenching treatment & Tempering/air cooled treatment & Phases present & Precipitates after tempering \\
\hline $2 \mathrm{Cr}-2 \mathrm{~W}$ & $930^{\circ} \mathrm{C} / \mathrm{hr}$ & $730^{\circ} \mathrm{C} / \mathrm{hr}$ & Bainite & $\mathrm{M}_{23} \mathrm{C}_{6}, \mathrm{M}_{6} \mathrm{C}, \mathrm{M}_{2} \mathrm{C}$ \\
$5 \mathrm{Cr}-2 \mathrm{~W}$ & $930^{\circ} \mathrm{C} / \mathrm{hr}$ & $750^{\circ} \mathrm{C} / \mathrm{hr}$ & Bainite & $\mathrm{M}_{23} \mathrm{C}_{6}$ \\
$9 \mathrm{Cr}-2 \mathrm{~W}$ & $950^{\circ} \mathrm{C} / \mathrm{hr}$ & $750^{\circ} \mathrm{C} / \mathrm{hr}$ & Martensite & $\mathrm{M}_{23} \mathrm{C}_{6}$ \\
$12 \mathrm{Cr}-2 \mathrm{~W}$ & $1000^{\circ} \mathrm{C} / \mathrm{hr}$ & $750^{\circ} \mathrm{C} / \mathrm{hr}$ & Martensite $+\delta$-ferrite $(0.16)$ & $\mathrm{M}_{23} \mathrm{C}_{6}$ \\
$15 \mathrm{Cr}-2 \mathrm{~W}$ & $1050^{\circ} \mathrm{C} / \mathrm{hr}$ & $750^{\circ} \mathrm{C} / \mathrm{hr}$ & Martensite $+\delta$-ferrite $(0.16)$ & $\mathrm{M}_{23} \mathrm{C}_{6}$ \\
\hline
\end{tabular}

steels such as $0.5 \mathrm{Cr} 0.5 \mathrm{Mo} 0.25 \mathrm{~V}, 1 \mathrm{CrMoV}$, and $2.25 \mathrm{Cr} 1 \mathrm{Mo}$, the compositions of which are given in Table 3, along with some other common creep-resistant steels.

These alloys have formed the backbone of the power generation and petrochemical industries for over 50 years for operating temperatures of $565^{\circ} \mathrm{C}$ or less. 2.25Cr1Mo steel is widely used for superheater tubing in power plant and as filler materials for joining $0.5 \mathrm{Cr} 0.5 \mathrm{Mo} 0.25 \mathrm{~V}$ steam piping [26].

The primary microstructures of these low alloy creepresistant steels are essential for leaner steels, allotriomorphic ferrite, and pearlite [6]. In other words, about a decade ago or so, for the classical or common creep steels, the best established steels relied on allotriomorphic ferrite or bainite as the starting microstructure. These microstructures contain very small grains of the order of a quarter of a micron, which provide additional opposition to the movement of dislocations. If diffusion creep was prevalent in these materials, a large grain size would be needed to increase the energy required for diffusion between and through grains [6].

To mitigate oxidation and corrosion in these creep steels, deliberate increase in the concentration of chromium was made. Consequently, $\delta$-ferrite formed, which is detrimental to creep strength. To eliminate this ferrite from the microstructure, balancing additions of other alloying elements were added leading to sufficient increase in the hardenability of the steel. On normalization heat treatment, it is found that the microstructure of this new steel system became martensite instead of bainite for identical cooling conditions.

Abe and Nakazawa (1992) [5] presented a study on the effect of varying chromium content on creep steel. The summary of their study is shown in Table 4.

By varying the chromium content of simple $2 \mathrm{wt} \% \mathrm{~W}$ steel, the microstructure changes from bainitic to martensitic and then to a dual-phase matrix of martensite and $\delta$-ferrite of about 0.16 volume fraction. $\delta$-ferrite is coarse and soft and consequently detrimental to creep strength. The phase can form during the solidification of ferritic steels [27-29]. In other words, higher alloy content steel, such as 9-15 wt\% Cr

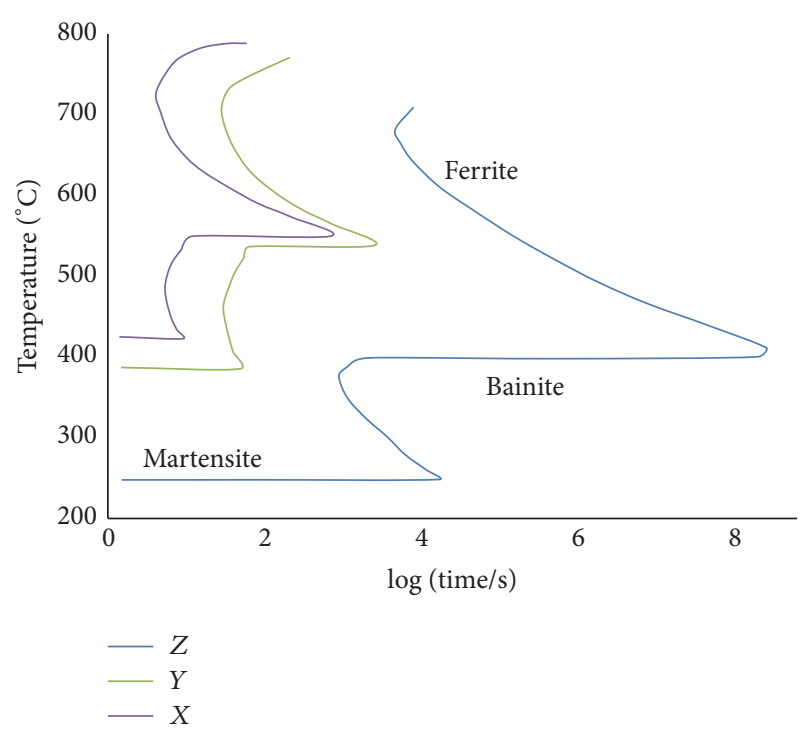

FIgURE 1: Calculated TTT diagrams for steels of composition $X$ (0.15C-0.2Si-0.5Mn-1Mo-2.3Cr wt\%), Y (4.3Cr wt\%), and $Z$ (9.3Cr wt\%) [9-12].

steels, tends to be martensitic on cooling rather than bainitic. This is because, as already mentioned, the larger alloy content causes an increase in the hardenability of the steel to the point where it cannot transform to bainite. This is illustrated by the calculated time-temperature transformation (TTT) diagrams for $2.3(X), 4.3(Y)$, and $9.3(Z)$ wt\% chromium steels shown in Figure 1.

In Figure 1, the upper curve for each case represents diffusion transformation, whereas the lower curve represents bainite. In general, 9-15 wt\% Cr steels are fully air hardened, meaning that the microstructure formed on air cooling from normalizing is completely martensitic. Therefore, martensitic matrix is seen as arising by chance. The martensite microstructure is reported to turn out to be the most exciting 
TABLE 5: Nominal chemical compositions (wt\%) of ferritic steels.

\begin{tabular}{|c|c|c|c|c|c|c|c|c|c|c|c|c|}
\hline Steels & $\mathrm{C}$ & $\mathrm{Si}$ & $\mathrm{Mn}$ & $\mathrm{Cr}$ & Mo & $\mathrm{W}$ & $\mathrm{Co}$ & $\mathrm{V}$ & $\mathrm{Nb}$ & $\mathrm{B}$ & $\mathrm{N}$ & Others \\
\hline \multicolumn{13}{|l|}{$2 \mathrm{Cr}$} \\
\hline $\mathrm{T} 22$ & 0.12 & 0.3 & 0.45 & 2.25 & 1.0 & - & - & - & - & - & - & - \\
\hline $\mathrm{HCM} 2 \mathrm{~S}$ & 0.06 & 0.20 & 0.45 & 2.25 & 0.1 & 1.60 & - & 0.25 & 0.05 & 0.003 & - & - \\
\hline \multicolumn{13}{|l|}{$9 \mathrm{Cr}$} \\
\hline T9 & 0.12 & 0.60 & 0.45 & 9.00 & 1.0 & - & - & - & - & - & - & - \\
\hline HCM9M & 0.07 & 0.30 & 0.45 & 9.00 & 2.0 & - & - & - & - & - & - & - \\
\hline Т91 & 0.10 & 0.40 & 0.45 & 9.00 & 1.0 & - & - & 0.20 & 0.08 & - & 0.05 & - \\
\hline NF616 & 0.07 & 0.06 & 0.45 & 9.00 & 0.5 & 1.80 & - & 0.20 & 0.05 & 0.004 & 0.06 & - \\
\hline Tempaloy F-9 & 0.06 & 0.50 & 0.60 & 9.00 & 1.0 & - & - & 0.25 & 0.40 & 0.005 & - & - \\
\hline EM12 & 0.10 & 0.40 & 0.10 & 9.00 & 2.0 & - & - & 0.30 & 0.40 & - & - & - \\
\hline \multicolumn{13}{|l|}{$12 \mathrm{Cr}$} \\
\hline НТ91 & 0.20 & 0.40 & 0.60 & 12.0 & 1.0 & - & - & 0.25 & - & - & - & $0.5 \mathrm{Ni}$ \\
\hline HT9 & 0.20 & 0.40 & 0.60 & 12.0 & 1.0 & 0.5 & - & 0.25 & - & - & - & $0.5 \mathrm{Ni}$ \\
\hline HCM12 & 0.10 & 0.30 & 0.55 & 12.0 & 1.0 & 1.0 & - & 0.25 & 0.05 & - & 0.03 & - \\
\hline HCM12A & 0.11 & 0.10 & 0.60 & 12.0 & 0.4 & 2.0 & - & 0.20 & 0.05 & 0.003 & 0.06 & $1.0 \mathrm{Cu}$ \\
\hline NF12 & 0.08 & 0.20 & 0.50 & 11.0 & 0.2 & 2.6 & 2.5 & 0.20 & 0.07 & 0.004 & 0.05 & - \\
\hline SAVE12 & 0.10 & 0.30 & 0.20 & 11.0 & - & 3.0 & 3.0 & 0.20 & 0.07 & - & 0.04 & $\begin{array}{c}0.07 \mathrm{Ta} \\
0.04 \mathrm{Nd}\end{array}$ \\
\hline
\end{tabular}

ferritic creep-resistant steels. Consequently, modern heatresistant steels are based on martensite microstructure. These higher alloy content steels for higher temperatures and greater corrosion/oxidation resistance are generally referred to as 9-12 wt\% Cr steels [6, 27-29] for the well-established ones.

Martensitic steels usually have to be tempered in order to obtain an optimum combination of strength and toughness. The tempering process usually leads to a decrease in strength due to the precipitation of iron carbides from carbon that was originally in solid solution in the martensite. However, when the steel contains strong carbide forming elements such as $\mathrm{Mo}, \mathrm{Cr}, \mathrm{V}, \mathrm{Ti}$, and $\mathrm{W}$, it becomes possible to recover the strength during prolonged tempering at elevated temperatures. This is called secondary hardening; it occurs because substitutional alloying elements (such as $\mathrm{Cr}$ ) can diffuse during prolonged annealing to precipitate finely dispersed alloy carbides.

The alloy carbides in secondary-hardened steels are found to be more thermodynamically stable than iron carbides and show little tendency to coarsen. However, many of the alloy carbides find it difficult to nucleate, so that the equilibrium carbide is not necessarily the first to precipitate. Instead, there is a sequence of alloy carbides precipitated in an order determined by a combination of kinetic and thermodynamic considerations which leads ultimately towards an equilibrium microstructure.

Many of the precipitates found in power plant steels have crystal structures and compositions which are quite different from those of the ferrite matrix. The precipitate/matrix interfacial energy can therefore be expected to be large, making it difficult for the equilibrium precipitate to nucleate. Consequently, decomposition often starts with the formation of one or more metastable phases which are kinetically favoured. These initial phases eventually dissolve as equilibrium is approached. The phases normally appear and reappear in the course of the microstructure attaining equilibrium. This progression towards equilibrium at service temperatures makes creep steels useful. It is well established that the fracture toughness of many power plant steels deteriorates during service at elevated temperatures for two reasons. Firstly, the carbide particles, particularly those located at the prior austenite boundaries, coarsen and hence provide easier sites for crack or void nucleation. Secondly, the elevated temperatures permit the impurities to diffuse relatively rapidly and saturate the boundaries.

Table 5 shows the composition of a selection of ferritic power plant steels.

One can see that there are three main, well-established groups of ferritic power plant steels as shown in Table 5, usually designated 2, 9, and $12 \mathrm{wt} \% \mathrm{Cr}$ steels. The $9-12 \mathrm{wt} \%$ $\mathrm{Cr}$ steels are currently undergoing the most research and development due to their high strength and good corrosion resistance. However, research has been done [8, 17, 30, 31] and currently going on in the development of 15Cr1Mo creepresistant steels for power plant temperatures up to $700^{\circ} \mathrm{C}$.

\section{Heat Treatment of Power Plant Steels}

In general, the primary microstructures of power plant alloys often consist of $\delta$-ferrite, martensite, bainite, allotriomorphic ferrite, and retained austenite as the major phases obtained following a normalizing heat treatment [32]. The phases formed in these alloy steels are dependent not only on the elements that make up their composition but also on the heat treatments applied to the components before they go into service. Studies have demonstrated how easy it is to change the microstructure of the steels by making little change in 
the alloy content. The situation can be further complicated by heat treatments applied to the steel, which can have a large effect on the microstructure and the mechanical properties. The heat treatment produces carbides and precipitates that have a direct effect on the properties of the steel. The main intention of the heat treatment is to optimize the mechanical properties of the alloy and to relieve stresses. Generally, two types of heat treatment are applied: a normalization treatment and a tempering treatment.

Normalization involves austenitization at a high temperature in order to dissolve many of the alloying elements into solid solution. The temperature is usually high enough to dissolve stable precipitates already in the steel. The precipitate may be carbides and nitrides so that on cooling from austenitizing temperature they precipitate as a fine dispersion of particles. The austenitization temperature that gives complete dissolution of precipitates varies for different alloy compositions. A too low temperature gives incomplete dissolution of carbide and this leads to loss of creep rupture strength in $12 \mathrm{Cr}-\mathrm{Mo}-\mathrm{V}$ steel. A too high temperature gives undesirable formation of $\delta$-ferrite phase. Recent publications have emphasised that a high $\mathrm{Ac}_{1}$ temperature (where austenite formation first begins during heating) leads to good creep strength [33-35].

After austenitization, the cooling rate will determine the phases that are formed from austenite and depends on alloy composition. In some low alloy steels slow cooling may form undesirable ferrite. Formation of ferrite, or low bainite if the cooling is too fast, will result in an unsatisfactory distribution of carbides, and this is found to affect creep properties. To control cooling rates modifying composition to change the hardenability or using a suitable cooling medium is necessary.

The normalization is usually followed by tempering heat treatment to obtain the required mechanical properties. This tempering process nucleates precipitates and relieves stress. It is well established that the creep properties improve with subsequent tempering and then eventually degrade after the precipitation of the larger equilibrium alloy carbides. Most creep steels are subjected to very severe tempering $\left(\sim 700^{\circ} \mathrm{C}\right.$ for several hours) causing general coarsening and the precipitation of ever more stable alloy carbides and intermetallic compounds. The precipitates, phases and composition of a steel, and the heat treatments applied to it are all important and interacting factors affecting creep properties. It is these solid-state reactions which ultimately determine the mechanical stability of the steels and, hence, their useful design lives [32].

In practice, two tempering heat treatments are often applied to the alloys after normalization. The first is meant to eliminate any retained austenite in the microstructure as this could influence dimensional stability. An initial temper of $500^{\circ} \mathrm{C}$ can induce the decomposition of the austenite so machining can be carried out accurately. The second is to produce a "stable" microstructure consisting of a variety of alloy carbides in a ferritic matrix. This tempering produces the required mechanical properties.

Tempering is carried out below the austenite transformation temperature so that there is no transformation to austenite. Temperature may be in excess of $500^{\circ} \mathrm{C}$ in
TABLE 6: Typical heat treatments schedule for power plant steels where Y0336, Z1092, A, and B are names for some developed creep steels [6].

\begin{tabular}{lcccc}
\hline Steel & Y0336 & Z1092 & A & B \\
\hline Normalization & & & & \\
Temperature, ${ }^{\circ} \mathrm{C}$ & 1053 & 1048 & 1200 & 1180 \\
Duration, hr & 11.35 & 11.6 & 2 & 2 \\
Cooling rate & $\mathrm{AC}$ & $\mathrm{AC}$ & $\mathrm{AC}$ & $\mathrm{AC}$ \\
Tempering & & & & \\
Temperature, ${ }^{\circ} \mathrm{C}$ & 750 & 742 & 800 & 800 \\
Duration, hr & 12.67 & 12.5 & 4 & 4 \\
Cooling rate & $\mathrm{AC}$ & $\mathrm{AC}$ & $\mathrm{AC}$ & $\mathrm{AC}$ \\
Annealing & & & & \\
Temperature, ${ }^{\circ} \mathrm{C}$ & - & - & 740 & 740 \\
Duration, hr & - & - & 4 & 4 \\
Cooling rate & - & - & $\mathrm{AC}$ & $\mathrm{AC}$ \\
\hline
\end{tabular}

AC: air cool.

order to allow the diffusion of substitutional atoms over the dimensions of precipitate growth in a reasonable period of time. 2.25CrlMo steel is usually given a stress-relief heat treatment at $700^{\circ} \mathrm{C}$ for several hours before going into service at a temperature of approximately $565^{\circ} \mathrm{C}$ [4]. The conditions chosen affect the precipitate size and creep properties. The initial precipitations formed are those for which nucleation is easiest. At longer times, mores table phases may form with the complimentary dissolution of the less stable carbides. Although the nucleation of these latter phases is more difficult, their formation leads to a reduction in the free energy of the system and so is thermodynamically preferable. Typical heat treatment schedule in the design of novel creep steel by Cole (2000) [6] is shown in Table 6.

The heat treatments applied to these steels have to be carefully chosen and controlled to produce a suitable microstructure. The choice has to take into account the composition of the alloy and the phases which will be formed. Normalizing at a too low temperature or tempering at a too high temperature could have a deleterious effect on the creep rupture strength.

Study has shown clearly that carbide particle sizes increase with tempering temperature. This growth is undesirable for creep properties, since a dispersion of fine particles is desired. Sikka et al. (1984) [36] reported that tempering 9Cr1 Mo alloy above a nominal temperature of $760^{\circ} \mathrm{C}$ produced insignificant effects on creep rupture strength, but tempering below this temperature significantly improved it.

\section{Description of Carbides in Power Plant Steels}

The evolution of microstructure in steel is a complex and dynamic process involving simultaneous transformations of different types of phases. All the products compete for the limited nucleation sites, resources, and space. A fast cooling condition can preserve the austenite into lower temperature 
regions, so that finer structures prevail. When many transformations occur at the same time, the fast reaction may consume much of the austenite. The migration of carbon through interstices, the creation rate of nuclei on the austenite grain boundaries, the growth rates of individual phases, and so forth all react and interact with each other [1].

The task in designing power plant steels is usually to model the evolution of these precipitates and dissolution reactions. In dealing with precipitations in creep steels, a simple notation system is used to describe the chemical formula of the precipitate. Here " $M$ " is used to represent the metal content (mixture of metal atoms) and " $\mathrm{X}$ " represents the carbon and nitrogen content.

There are varieties of phases that could be found in these power plant steels. The following list shows the well-known precipitates that determine the microstructure of power plant steels and are crucial in the development of creep strain [15].

Types of Precipitates That Can Be Found in Power Plant Steels $[15,20]$. They are listed as follows:

Possible phases
Graphite
Epsilon $\mathrm{Fe}_{2.4} \mathrm{C}$
Cementite $\mathrm{Fe}_{3} \mathrm{C}$
$\mathrm{Chi} \mathrm{Fe}_{2} \mathrm{C}$
$\mathrm{M}_{2} \mathrm{X} \mathrm{M}_{6} \mathrm{C} \mathrm{M}_{23} \mathrm{C}_{6} \quad \mathrm{M}_{7} \mathrm{C}_{3}$ Laves
$\mathrm{M}_{5} \mathrm{C}_{2}$ Z-phase $\mu$-Phase $\chi$-phase

$\mathrm{M}_{5} \mathrm{C}_{2}$ is among the latest discovery in $1 \mathrm{Cr}-0.5 \mathrm{Mo}$ steels. $\mu$ phase has also been discovered.

Since these precipitates are often metastable, they do not represent the lowest free energy state. They form because they nucleate easily and they may dissolve as the material approaches equilibrium with time. Therefore, the first alloy carbide to form is generally not the equilibrium carbide, leading to precipitation sequences that produce more stable carbides $[6,15]$. Sometimes, carbides which are metastable at first become stable during service when the composition of the steel changes. This is reported to happen when two different kinds of steels are joined together, leading to diffusion fluxes across the junction.

Cementite is iron-rich carbide that forms very rapidly, whereas graphite, despite an equilibrium phase, forms incredibly slowly since it is difficult to nucleate. Cementite containing no alloying element additions is seen to have an approximately hexagonal close-packed $(h c p)$ arrangement of metal atoms with localized distortions to accommodate the carbon atoms or simply has an orthorhombic structure. The structure of cementite containing no alloying element additions has the structure $\mathrm{Fe}_{3} \mathrm{C}$.

$\mathrm{M}_{3} \mathrm{C}$ denotes predominantly an iron-rich carbide with the same orthorhombic structure as $\mathrm{Fe}_{3} \mathrm{C}$, but here several other alloying elements can be found to partition into this carbide in significant quantities. Other metal elements can substitute for iron in alloy steels. The unit cell dimensions are found to be affected by partial substitution of alloying elements. Mn is found to dissolve in large quantities, as can
$\mathrm{Cr}$, with up to one-fifth of the Fe atoms being replaced by $\mathrm{Cr}$ (specific to low alloy steels). $\mathrm{Ni}$ and Co can also dissolve as they form metastable orthorhombic carbides, although it is found that they usually partition to ferrite. Mo, $\mathrm{W}$, and $\mathrm{V}$ have also been found to have limited solubilities in $\mathrm{M}_{3} \mathrm{C}$. In general, $\mathrm{M}_{3} \mathrm{C}$ carbides can be referred to using the general formula ( $\mathrm{Fe}, \mathrm{Cr}, \mathrm{Mn}, \mathrm{Mo})_{3} \mathrm{C}$ [26].

Tempering causes the cementite to enrich towards its equilibrium composition. It is found that the rate of enrichment is fastest when the particles are of small size and the ferrite is saturated in carbide forming solute atoms [26, 32]. In low $\mathrm{Cr}$ steels, it is found that the cementite will enrich slowly and is unlikely to reach its equilibrium composition in the component lifetime but in high $\mathrm{Cr}$ and high alloy steels the cementite enriches rapidly and then dissolves as other alloy carbides precipitate. This phenomenon is believed to be the basis of secondary hardening in these steels. The steel softens as the cementite forms and removes carbon from solid solution but is then hardened by the alloy carbides which interact with dislocations, thus giving the so called secondary hardening. It is possible to form more stable carbides, nitrides, and borides than cementite. These are seen to form by the dissolution of a relatively coarse cementite dispersion which is replaced by finer alloy carbide dispersion [32].

It is found that when strong carbide forming elements are present, alloy carbides would form in preference to cementite. However, alloy carbides do not form until the steels are tempered in the range of $500-600^{\circ} \mathrm{C}$ because the metallic alloying elements cannot diffuse sufficiently rapidly to allow the alloy carbides to nucleate. Carbon, like nitrogen, can diffuse much more rapidly since it moves interstitially through the iron lattice; thus iron carbide tends to be the first precipitates formed in these steels.

In many cases $\mathrm{M}_{2} \mathrm{X}$ type precipitates are found to be the first to form after cementite and they have a hexagonal crystal structure $(h c p)$. Here, $\mathrm{M}$ denotes one or more of these alloying elements, $\mathrm{V}, \mathrm{Cr}, \mathrm{Mn}, \mathrm{Fe}, \mathrm{Ni}, \mathrm{Nb}, \mathrm{Mo}, \mathrm{Ta}$, and $\mathrm{W}$; X represents $\mathrm{C}$ or $\mathrm{N}$. It has been determined that in complex steels the phase is best regarded as $(\mathrm{Cr}, \mathrm{Mo}, \mathrm{V})_{2}(\mathrm{C}, \mathrm{N})$. Study found that, in Mo steel containing low $\mathrm{Cr}$ content and no nitrogen, such as $2.25 \mathrm{Cr}-1 \mathrm{Mo}$ steels, $\mathrm{M}_{2} \mathrm{X}$ is often close to $\mathrm{Mo}_{2} \mathrm{C}$ [37]. In 9$12 \mathrm{wt} \% \mathrm{Cr}$ steels containing nitrogen, the composition of $\mathrm{M}_{2} \mathrm{X}$ is found to be closer to $\mathrm{Cr}_{2} \mathrm{~N}$.

$\mathrm{M}_{2} \mathrm{X}$ is found to exist as fine needle-like particles dispersed throughout the matrix and generally considered to nucleate on dislocations and martensite lath boundaries. Its precipitation is found to often cause secondary hardening, which is particularly seen to be important for low alloy steels, where $\mathrm{M}_{2} \mathrm{X}$ plays a major role in the creep strength of the alloy. The precipitation of $\mathrm{Mo}_{2} \mathrm{C}$ is usually seen to be the major factor in conferring creep resistance on low alloy ferritic steels. Study found that increasing $\mathrm{Ni}$ contents in steel decreases the stability of $M_{2} X$ phase [26].

Stabilization of a Cr-rich $\mathrm{M}_{2} \mathrm{X}$ phase in $12 \mathrm{wt} \% \mathrm{Cr}$ steels can also cause secondary hardening [38]. Unfortunately, the elements which stabilize $\mathrm{M}_{2} \mathrm{X}$ such as $\mathrm{Cr}$ and Mo are seen to cause the formation of $\delta$-ferrite, a phase detrimental to 
creep properties, therefore limiting the quantities which may be added.

In their study, Baker and Nutting (1959) [37] observed that $M_{7} C_{3}$ forms after the formation of $M_{2} X$ (i.e., $M_{2} C$ ). $\mathrm{M}_{7} \mathrm{C}_{3}$ is a Cr-rich carbide with the trigonal structure of $\mathrm{Cr}_{7} \mathrm{C}_{3}$, having a solubility of $\mathrm{Fe}$ up to $60 \%$. This phase can form after cementite formation $\left(\mathrm{M}_{3} \mathrm{C}\right)$ without any $\mathrm{M}_{2} \mathrm{X}$ being observed. In Thompson's review, Titchmarsh (1978) [39] is said to have found that the $\mathrm{Cr}$ : Fe ratio can be greater than 1 in 2.25Cr1Mo steel. Mn, V, and Mo can also dissolve, with decreasing probabilities, respectively.

It has been found that $\mathrm{M}_{7} \mathrm{C}_{3}$ tends to nucleate in the vicinity of cementite or at the cementite/ferrite interface of a 2.25Cr-1Mo steel. $\mathrm{M}_{7} \mathrm{C}_{3}$ seemed to be observed if a sufficient $\mathrm{Cr}$ concentration is available. The dissolution of cementite is seen to provide an area sufficiently rich in chromium in which $\mathrm{M}_{7} \mathrm{C}_{3}$ could precipitate since these will be the most favourable sites $[32,40]$. This phase has been found to coarsen rapidly and gave no beneficial contribution to creep rupture strength.

$\mathrm{M}_{23} \mathrm{C}_{6}$ is chromium-rich carbide which precipitates after either $\mathrm{M}_{7} \mathrm{C}_{3}$ or $\mathrm{M}_{2} \mathrm{X}$ in $9-12 \mathrm{wt} \% \mathrm{Cr}$. It is observed to possess complex $f c c$ structure of $\mathrm{Cr}_{23} \mathrm{C}_{6}$ [26] and the precipitate may also contain $\mathrm{W}, \mathrm{Mo}, \mathrm{V}$, and $\mathrm{Ni}[5,6,41]$. In steels containing significant amounts of Mo, it is believed that the formula $\mathrm{Fe}_{21} \mathrm{Mo}_{2} \mathrm{C}_{6}$ can result and that in steels containing both $\mathrm{Cr}$ and $\mathrm{Mo}$ its composition can be anywhere within the above. This carbide is often found to precipitate with equilibrium composition and is predominant after tempering [42]. The phase is found to nucleate on the prior austenite grain boundaries or martensite lath boundaries or adjacent to $\mathrm{M}_{7} \mathrm{C}_{3}$.

Overaging is accompanied by the formation of $\mathrm{M}_{23} \mathrm{C}_{6}$ and dissolution of $\mathrm{M}_{2} \mathrm{X}$. It is then often found that $\mathrm{M}_{2} \mathrm{X}$ dissolves after long-term exposure at high temperature in 9$12 \mathrm{wt} \% \mathrm{Cr}$ steels and so does not improve the long-term creep resistance. It was also found that vanadium stabilizes $\mathrm{M}_{7} \mathrm{C}_{3}$ and so decreases the rate of release into the matrix of carbon and chromium for the growth of $\mathrm{M}_{23} \mathrm{C}_{6}$.

Various studies show that the composition of $\mathrm{M}_{23} \mathrm{C}_{6}$ varies with time. The carbide is found to enrich in Fe after 5 years in $2.25 \mathrm{Cr}-1 \mathrm{Mo}$ steels with a high $\mathrm{Cr}$ content with some low Mo content and after 18 years in service the phase contained much more chromium-rich $\mathrm{M}_{23} \mathrm{C}_{6}$. The carbide $\mathrm{M}_{23} \mathrm{C}_{6}$ is frequently observed in the form of large or coarse particles and is not thought to contribute directly to creep strength. That is, $\mathrm{M}_{23} \mathrm{C}_{6}$ is less effective in hindering creep deformation. Delaying its precipitation would have the effect of stabilizing the finer dispersions of $\mathrm{M}_{2} \mathrm{X}$ and $\mathrm{MX}$ to longer times with a possible enhancement of creep strength. Study has also shown that the tendency for $\mathrm{M}_{23} \mathrm{C}_{6}$ to coarsen should also be greatest in the Cr-rich alloys [6].

However, it has been suggested that $\mathrm{M}_{23} \mathrm{C}_{6}$ carbides may stabilize lath boundaries and delay grain growth. In his study, Abe (1999) [13] made a conclusion that $\mathrm{M}_{23} \mathrm{C}_{6}$ precipitates are the most effective in $9 \mathrm{Cr}-\mathrm{W}$ system for pinning lath boundaries and reducing the coarsening rate of the laths. This study shows that coarsening occurs by sideways movement of lath boundaries and the coalescence of two boundaries.

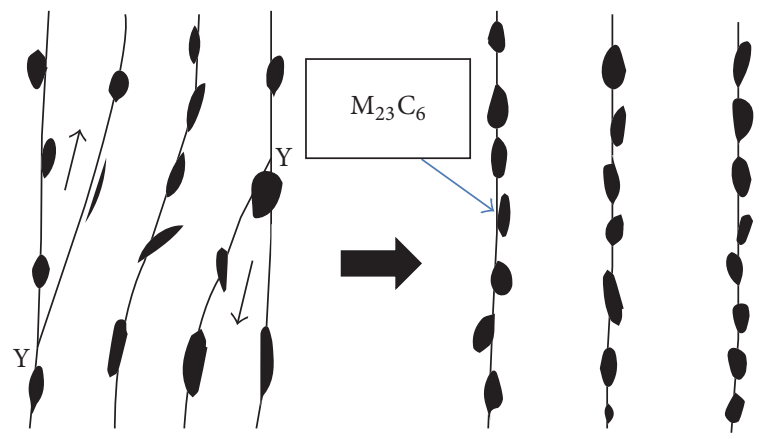

FIGURE 2: Schematic of coarsening of martensite laths by the movement of Y-junction in 9Cr-W steels during creep testing at 550$650^{\circ} \mathrm{C}$ for up to 15000 hours, with varying tungsten content $[6,13]$.

Figure 2 illustrates the movement of Y-junction of triple points of lath boundaries to cause coarsening.

Figure 3 shows an image obtained, using TEM, from a thin foil specimen of $9 \mathrm{Cr}$ steel given severe heat treatments.

The microstructure in Figure 3(a) shows tempered martensite which retains the essential lath-like morphology and carbides. The absence of coarsening is said to be due to stabilization of the microstructure by the carbides which nucleated heterogeneously at the lath boundaries [6]. Figure 3(b) shows carbides aligned at the martensite laths boundaries.

9Cr-Mo steels after creep test have shown preferential recovery of the microstructure in the vicinity of prior austenite grain boundaries. This recovery phenomenon is associated with carbides forming and coarsening preferentially at the prior austenite grain boundaries, removing solutes and dissolving smaller precipitates in the surrounding regions. The loss of pining effect by the precipitates allows the recovery of the martensitic microstructure [6]. This process is depicted schematically as in Figure 4 for a $12 \mathrm{Cr}$ alloy.

These mechanisms are reported to account for the loss in long-term creep strength often experienced by $9-12 \mathrm{Cr}$ wt $\%$ steels, caused by the coarsening of the microstructure. This process has been reported to have occurred for modified $9 \mathrm{Cr}$ 1 Mo steel at 600 and $650^{\circ} \mathrm{C}$ for 10000 hours [14]. Figure 5 shows degradation in creep rupture strength for a modified $9 \mathrm{Cr}-1 \mathrm{Mo}$ steel by this process.

For the improvement of long-term creep rupture strength, research has shown that the dissolution of small precipitates and the coarsening of large ones need to be retarded. Recovery of the microstructure also needs to be delayed, especially in the vicinity of prior austenite grain boundaries.

The coarsening of $\mathrm{M}_{23} \mathrm{C}_{6}$ carbides in $12 \mathrm{CrMo}(\mathrm{W}) \mathrm{VNbN}$ steel is reported to be accompanied by dissolution of fine MX carbonitrides. Increase in $\mathrm{Ni}$ content in $12 \mathrm{CrMoV}$ steel results in accelerated microstructure degradation with more rapid coarsening of $\mathrm{M}_{23} \mathrm{C}_{6}$, dissolution of $\mathrm{MX}$, and precipitation of coarse $\mathrm{M}_{6} \mathrm{X}$ and $\mathrm{Fe}_{2} \mathrm{Mo}$. Increase in nitrogen content results in accelerated microstructure degradation during creep at $650^{\circ} \mathrm{C}$ with more rapid precipitation of a phase referred to as Z-phase. 


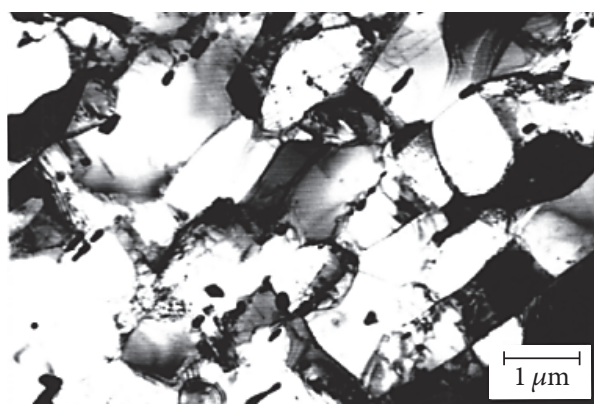

(a)

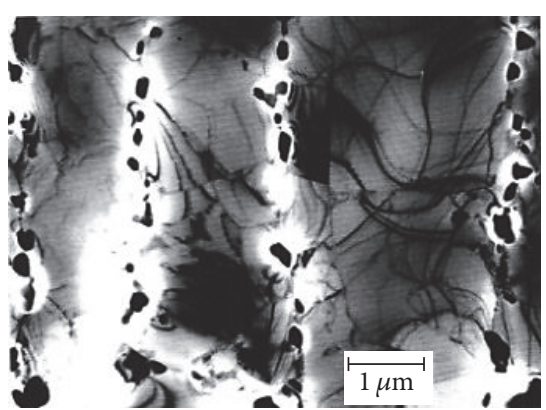

(b)

FIGURE 3: TEM micrograph of Z1092 (9Cr steel), showing the general microstructure [6].
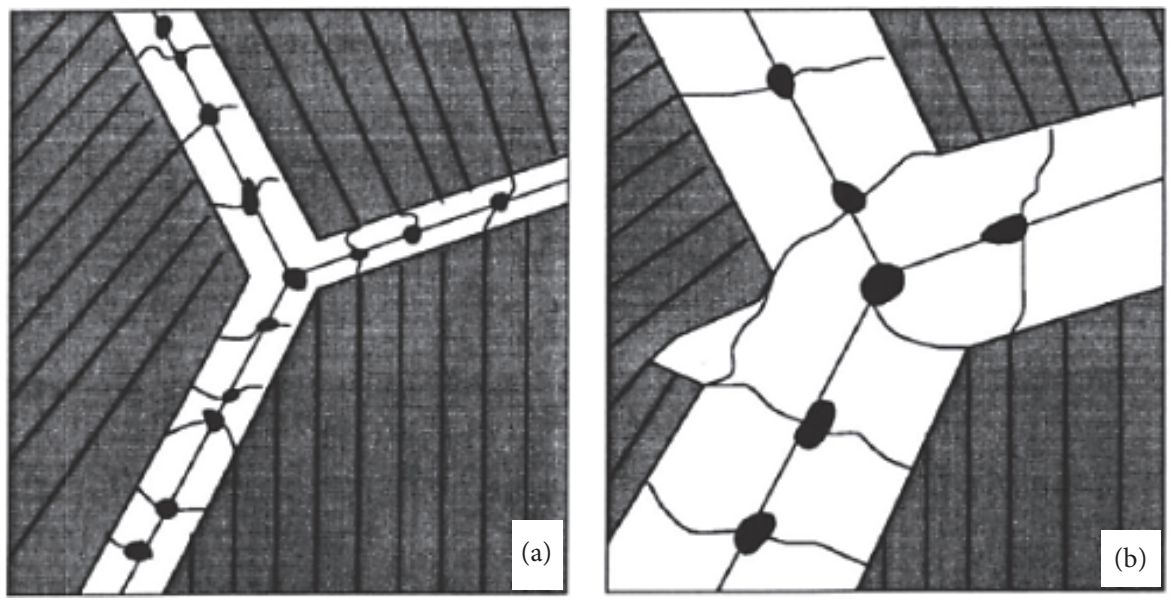

FIGURE 4: Illustration of the degradation mechanism of a 12Cr-0.4Mo-2W-Cu-V-Nb steel. (a) shows the microstructure prior to creep testing and (b) illustrates the microstructure after long-term creep deformation [6].

One of the important observations in the recent literature is that many ferritic steels are strong in creep in the early stages of creep life, but the strength then deteriorates sharply as a consequence of the development of local regions of recovery, where damage is then intensified. The observations reported in [6] confirm that recovery is not usually homogeneous. A possible solution is suggested of the use of a dual heat treatment to obtain more homogeneous dispersion of precipitates and retard localized recovery. The observations also support the design philosophy that the concentration of $\mathrm{Ni}$ should be minimized since it causes acceleration of microstructure degradation with more rapid coarsening of $\mathrm{M}_{23} \mathrm{C}_{6}$.

In Fe-9Cr-W steels, $\mathrm{W}$ content has been found to affect the coarsening of $\mathrm{M}_{23} \mathrm{C}_{6}$ during creep testing at $600^{\circ} \mathrm{C}$ [13], as shown in Figure 6. However, this information is usually interpreted with caution because the addition of tungsten also causes the precipitation of Laves phase (intermetallic compound) [13].

This study found that the coarsening of $\mathrm{M}_{23} \mathrm{C}_{6}$ and the martensite laths were reduced by increasing the amount of tungsten. The increase in $\mathrm{W}$ also caused the precipitation of Laves phase, which is said to be beneficial in decreasing creep rate and suppressing the recovery of the microstructure.
When steels contain Mo and relatively low level of $\mathrm{Cr}$, $\mathrm{M}_{6} \mathrm{C}$ precipitates, which seems to be the equilibrium carbide $[35,43]$. Therefore, $\mathrm{M}_{6} \mathrm{C}$ is found to be essentially Morich carbide with $f c c$ [26]. $\mathrm{M}_{6} \mathrm{C}$ is found to nucleate on $\mathrm{M}_{2} \mathrm{X}$ and $\mathrm{M}_{23} \mathrm{C}_{6}$ interphase boundaries, prior austenite grain boundaries, or martensite lath growing rapidly at the expense of all surrounding carbides, nucleating at existing particles [6]. The transformation of $\mathrm{Mo}_{2} \mathrm{C}$ to $\mathrm{M}_{6} \mathrm{C}$ is said to occur more rapidly in bainite than in ferrite.

Work reported by Nutting (1999) [44] indicates that this phase may not nucleate from existing carbides, but as the carbides dissolve, solutes are transferred to $\mathrm{M}_{6} \mathrm{C}$ by diffusion. The carbide is often coarse and since it causes the dissolution of less stable fine carbides; $\mathrm{M}_{6} \mathrm{C}$ can cause a reduction in creep strength. It has been shown that the coarsening rate of $\mathrm{M}_{6} \mathrm{C}$ is greater than that of $\mathrm{M}_{23} \mathrm{C}_{6}$ and so is a particularly undesirable phase in creep steel design. This carbide is found to be mainly rich in $\mathrm{Mo}$ in $0.5 \mathrm{Cr} 0.5 \mathrm{Mo} 0.25 \mathrm{~V}$ steel and precipitate in $12 \mathrm{CrMoV}$ steels with high Ni content [44].

MX denotes some carbides which may be observed in power plant steels and often has a cubic structure like $\mathrm{NaCl}$ [41]. It was observed to be often rich in vanadium, although $\mathrm{NbC}$ and $\mathrm{TiC}$ have also been found to form. The vanadium carbide structure is basically VC but extends to $\mathrm{V}_{4} \mathrm{C}_{3}$. There 


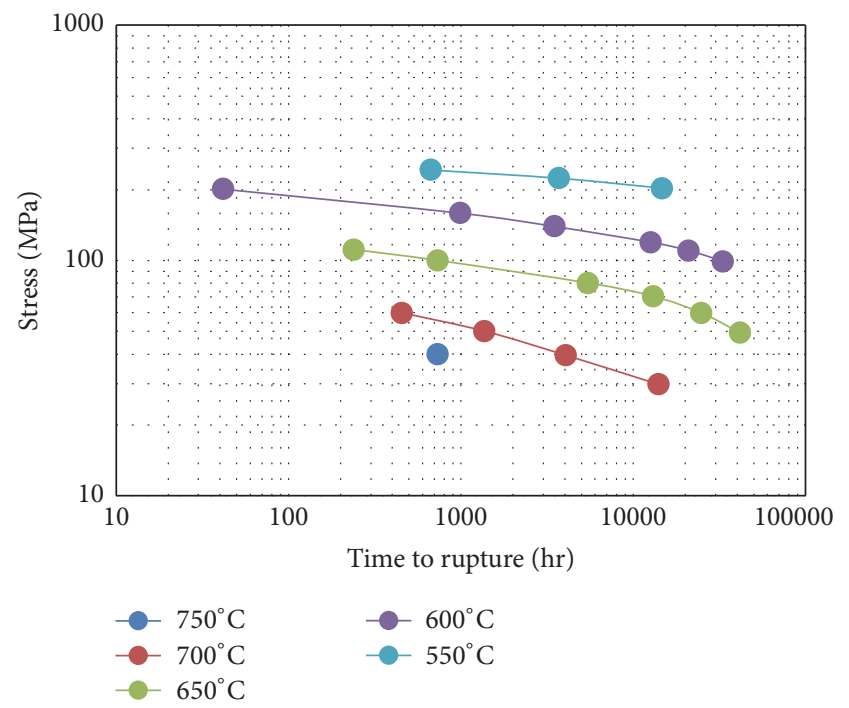

FIGURE 5: Degradation in creep rupture strength for a modified 9Cr$1 \mathrm{Mo}$ steel, adapted from [14] or stress versus time to rupture curves for 9Cr-1Mo (or T91).
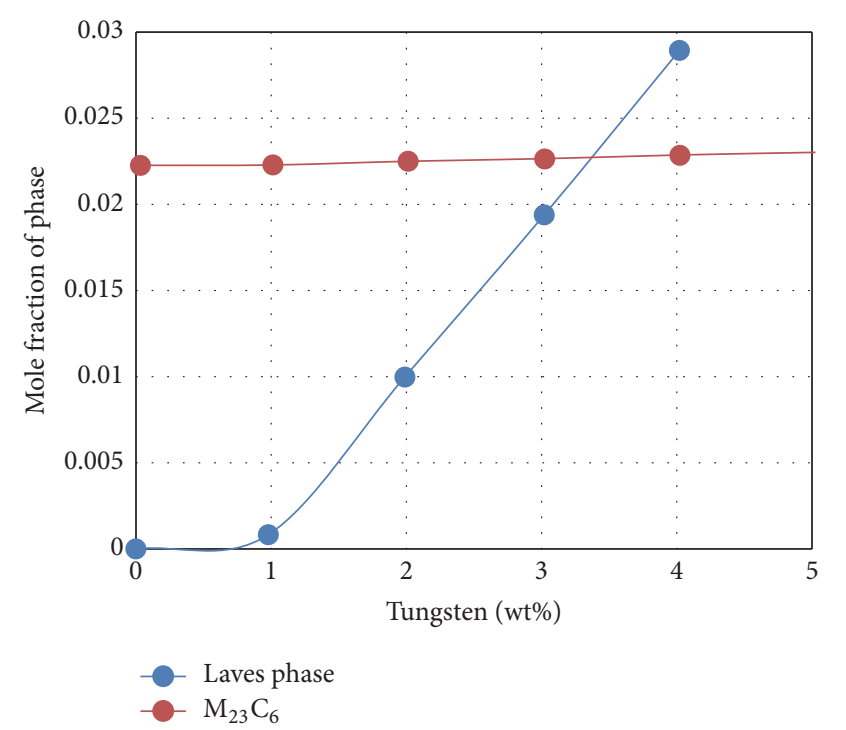

Figure 6: Coarsening data from Fe-0.1C-9Cr-0.5Mn-0.3Si wt\% steel, containing a variety of tungsten additions, tested in creep at $600^{\circ} \mathrm{C}[13]$.

is also some solubility of $\mathrm{Fe}, \mathrm{Cr}$, and $\mathrm{Mo}$ in these MC. The carbides MoC and WC were observed to have hexagonal structures. Other precipitates of this form such as VN were found to be desirable because they form a fine distribution of small and stable particles which are beneficial to creep strength. VN and NbC could be found in a $12 \mathrm{wt} \% \mathrm{Cr}$ steel containing $\mathrm{V}$ and $\mathrm{Nb}$. $\mathrm{VN}$ was found as a plate-like phase and $\mathrm{NbC}$ in a more spheroidal form.

After long exposure to elevated temperatures Laves phase precipitates and it has the general composition $\mathrm{Fe}_{2} \mathrm{M}$, where the alloy content may be W, Mo, or a combination of both. Laves phase is found to have a higher interfacial energy. It has often been observed in 9-12 wt\% Cr steels containing W or Mo and in 9Cr1Mo steel of approximate composition:

11 wt $\%$ Si, 44 wt\% Mo, 17 wt $\%$ Cr, and 28 wt\% Fe.

It was also found that this phase tends to form preferentially in Cr-depleted regions. These regions were found to be comparatively rich in Mo, indicating that a principal kinetic constraint on Laves phase formation is the diffusion of Mo atoms. It has been established that increasing the Si content of $9 \mathrm{Cr}-2 \mathrm{Mo}$ steel accelerates and increases Laves phase precipitation. It was found that $\mathrm{Mn}$ additions were useful in retarding the formation of Laves phase [45]. Precipitation of Laves phase on lath boundaries decreases creep rate and suppressed the recovery of the microstructure. A Si content of $0.3 \mathrm{wt} \%$ was found to provide the best balance between recovery of the microstructure and coarsening of the precipitate of some creep steel. Laves phase has been found to initially form on prior austenite grain boundaries followed by precipitation on lath boundaries and finally some precipitation within the laths [45]. It may also benefit from nucleation on existing phases such as $\mathrm{M}_{23} \mathrm{C}_{6}$. Study found formation of Laves phase at grain boundaries and martensitic lath interfaces were an important factor in maintaining creep rupture strength. For tungsten containing steels, Laves phase precipitation is found to be beneficial for creep strength than for solid solution strengthening by tungsten. Laves phase containing $\mathrm{W}$ is found to be thermally stable but the coarsening rate of the particles after precipitation is high [45]. This gives large Laves phase precipitates after several thousand hours of creep exposure, indicating that the beneficial effects for creep strength would not last into the long-term.

Laves phase is seen to be the equilibrium precipitate at temperatures below $\sim 600^{\circ} \mathrm{C}$ in the $10 \mathrm{CrMoV}$ steel. The variation of the equilibrium volume fraction with temperature is shown in Figure 7. From the graph, Laves phase is not observed beyond about $600^{\circ} \mathrm{C}$.

There have been a number of studies of Laves phase precipitation in 9CrMoWV steel (NF616) [46], a commercial alloy designated for service at temperatures above $600^{\circ} \mathrm{C}$ in power plant. The steel (wt\%: Fe-0.106C-8.96Cr$0.47 \mathrm{Mo}-0.051 \mathrm{~N}-0.069 \mathrm{Nb}-0.20 \mathrm{~V}-1.83 \mathrm{~W}$ ) contains tungsten which makes it more susceptible to Laves formation, which occurs over a greater range of temperatures than in the $10 \mathrm{CrMoV}$ steel. In the study in [47], Laves phase $\left(\mathrm{Fe}_{2} \mathrm{Mo}\right)$ and progressive coarsening of $(\mathrm{CrFe})_{23} \mathrm{C}_{6}$ carbides with respect to increasing test duration and temperature were observed. The formation and growth of $\mathrm{Fe}_{2} \mathrm{Mo}$ are reported to occur at $\mathrm{Cr}_{2} \mathrm{~N} /$ matrix interface, caused by the depletion of $\mathrm{Cr}$ solutes in the vicinity of $\mathrm{Cr}_{2} \mathrm{~N}$ precipitates [47].

Another phase usually found in $12 \mathrm{CrMoVNb}$ steels at temperature greater than $550^{\circ} \mathrm{C}$ is $\mathrm{Z}$-phase. This phase is a complex nitride phase containing $\mathrm{Cr}, \mathrm{V}$, and niobium (Nb) (of the form $\operatorname{Cr}(\mathrm{Nb}, \mathrm{V}) \mathrm{N}$ and it is found to form in close association with dissolving $\mathrm{NbX}$ particles [47, 48]. As this phase grows, it is seen to gradually replace $\mathrm{MX}$ and $\mathrm{M}_{2} \mathrm{X}$ nitrogen-rich phases which improve the creep rupture strength [49]. Therefore, Z-phase directly contributes to a reduction in the creep rupture strength of the observed 


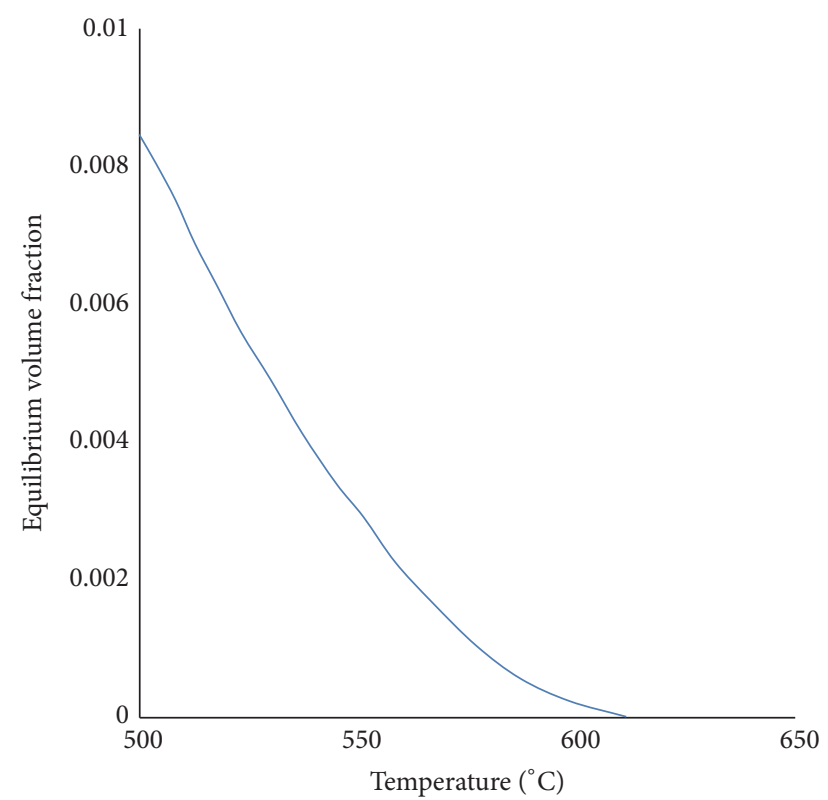

FIGURE 7: Variation of equilibrium volume fraction of Laves phase with temperature in $10 \mathrm{CrMoV}$ steel, calculated using MTDATA [7].

$12 \mathrm{CrMoVNb}$ steel. Precipitation of large Z-phase particles, $\mathrm{Cr}(\mathrm{V}, \mathrm{Nb}) \mathrm{N}$, which depletes the matrix of fine MX nitrides, $(\mathrm{V}, \mathrm{Nb}) \mathrm{N}$, was observed to be the major cause of early breakdown in long-term creep strength of a number of new $9-12 \%$ Cr martensitic steels [50].

Study shows that large concentration of niobium $(0.9 \mathrm{wt} \%)$ enhances the precipitation of $Z$-phase. In $12 \mathrm{Cr}$ steel used by [51], precipitation of Z-phase was observed to be accomplished by $\mathrm{Cr}$ atoms diffusing into $(\mathrm{V}, \mathrm{Nb}) \mathrm{N}$ particles and later this structure transforms to cubic or tetragonal Z-phase. It was also reported that Z-phase formed rapidly at prior austenite grain boundaries. Also the formation was fastest at $650^{\circ} \mathrm{C}$.

In general, the precipitation of Z-phase, $\mathrm{M}_{6} \mathrm{X}$, and $\mathrm{Fe}_{2}$ (W, Mo) Laves phase during creep causes a loss of creep strength at long times, because they consume existing fine $\mathrm{M}_{2} \mathrm{X}$ and $\mathrm{MX}$ and or $\mathrm{M}_{23} \mathrm{C}_{6}$ precipitates $[42,50]$. Retardation of the Z-phase formation is necessary to improve strength of creep-resistant steels [49].

Figure 8 is the sigmoidal behaviour in creep rupture data for four creep steels at $650^{\circ} \mathrm{C}$ showing the effect of Z-phase formation [16].

The synergetic effect of Z-phase precipitation and tungsten depletion of solid solution due to $\mathrm{Fe}_{2} \mathrm{~W}$ Laves phase formation is believed to be the reason for the sigmoidal shape of creep rupture strength curve of TAF 650 steel. The loss of creep strength in the modified 9Cr-1Mo (or T91) is reported [16] to be due to preferential recovery of the microstructure in the vicinity of prior austenite boundaries, as shown in Figure 9. The preferential recovery promotes the onset of acceleration creep and hence causes premature rupture. The dissolution of MX and the precipitation of Zphase are reported to promote the preferential recovery.

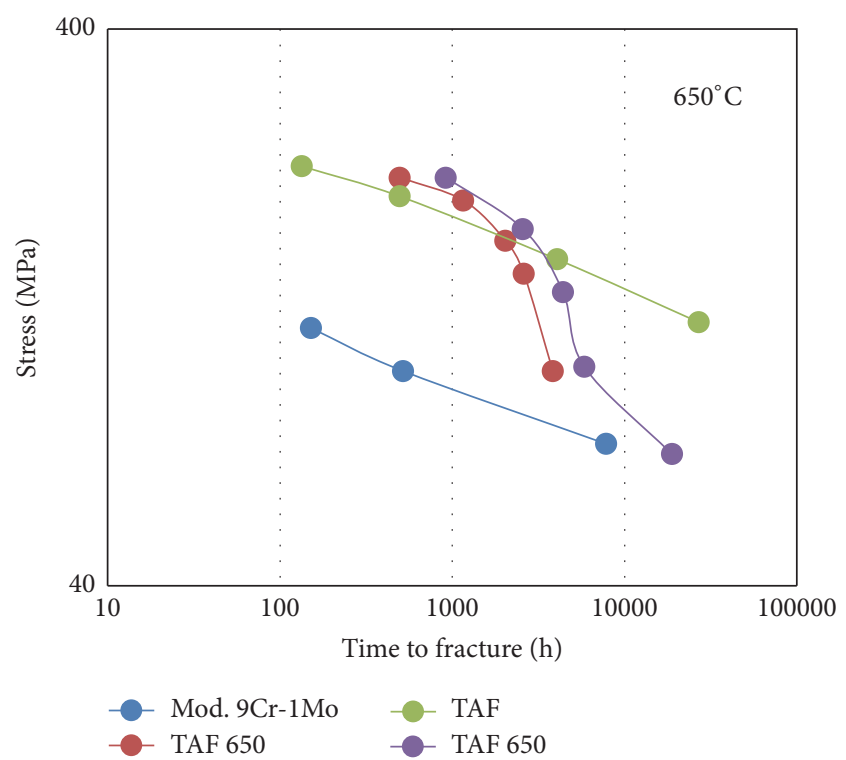

Figure 8: Comparison of stress versus time to rupture curves for various martensitic steels at $650^{\circ} \mathrm{C}$, adapted from [16].

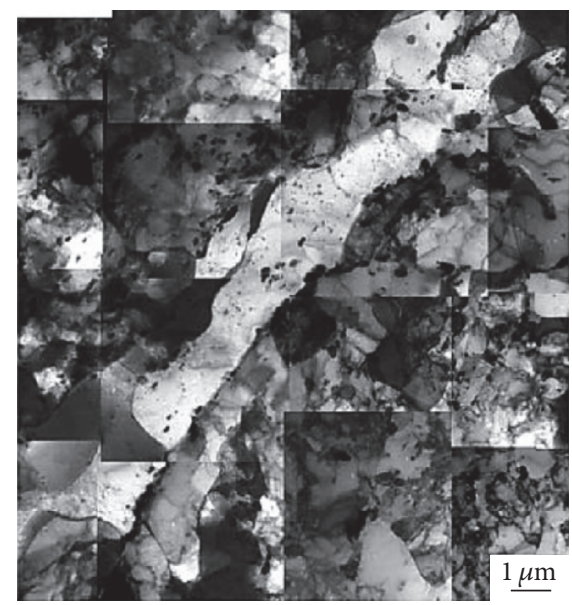

FIGURE 9: TEM micrograph after creep rupture testing for 34,141 hr at $600^{\circ} \mathrm{C}$ and $100 \mathrm{MPa}$ [16].

Generally, it is believed that the loss of creep strength in $9-12 \mathrm{Cr}$ steels at $550^{\circ} \mathrm{C}$ and above is due mainly to the dissolution of fine $\mathrm{M}_{2} \mathrm{X}$ and MX carbonitrides during creep exposure, which is driven by the precipitation of coarse Zphase and or $\mathrm{M}_{6} \mathrm{X}$ carbonitrides which are thermodynamically more stable than $\mathrm{M}_{2} \mathrm{X}$ and $\mathrm{MX}[16,52-54]$.

A report has been made on the discovery of $\mathrm{M}_{5} \mathrm{C}_{2}$ in exservice $1 \mathrm{Cr}-0.5 \mathrm{Mo}$ creep steels [55]. This phase is said to have a monoclinic structure and has not been identified before in creep-resistant Cr-No steels. The precipitates were found to be rod-shaped and appeared to nucleate heterogeneously on $\mathrm{M}_{2} \mathrm{C}$ and remain in ferrite regions from which $\mathrm{M}_{2} \mathrm{C}$ had disappeared, suggesting that $M_{5} C_{2}$ is more stable than $M_{2} X$. The discoveries of $\mathrm{M}_{5} \mathrm{C}_{2}$ and $\mathrm{Z}$-phase are more recent than the other phases in ferritic power plant steels. 


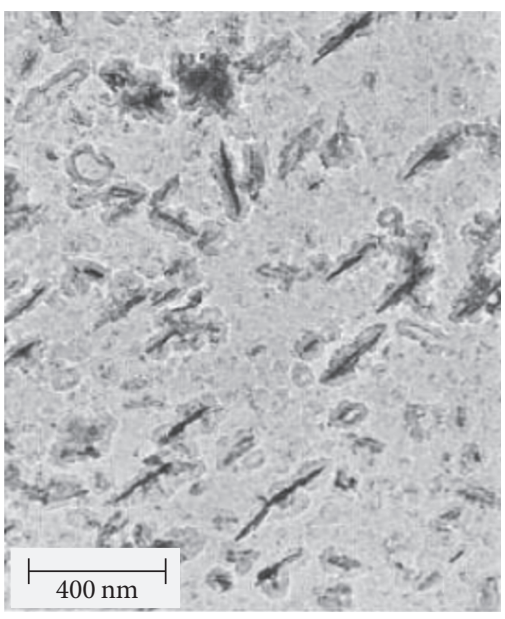

(a) $(10 \mathrm{~min})$

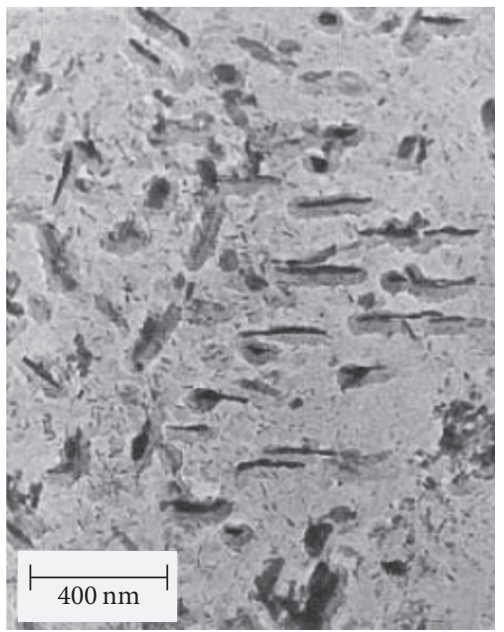

(c) $(1 \mathrm{hr})$

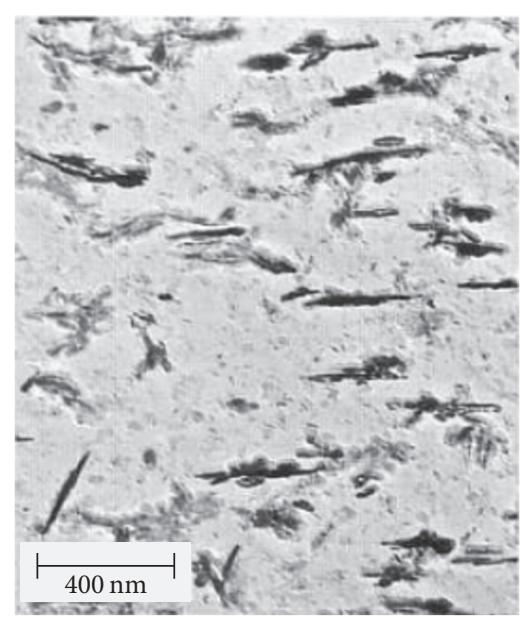

(b) $(30 \mathrm{~min})$

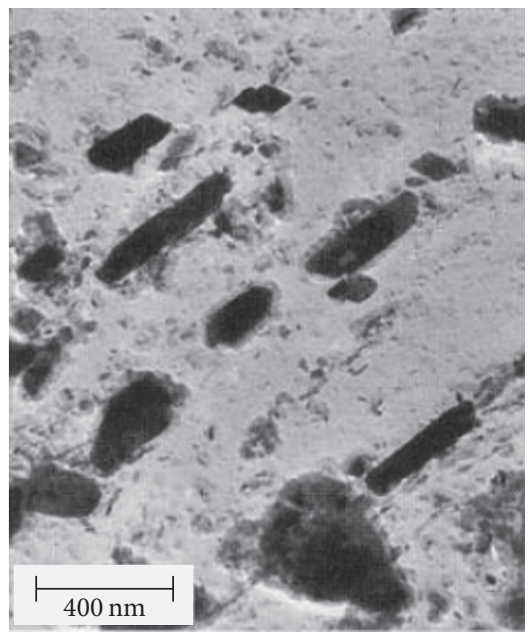

(d) $(16 \mathrm{hr})$

FIGURE 10: This figure shows micrographs which are examples of all the transitions observed at $600^{\circ} \mathrm{C}$. [7].

TABLE 7: Heat treatments of $10 \mathrm{CrMoV}$ steel for carbide stability study [7].

\begin{tabular}{lc}
\hline Temperature, ${ }^{\circ} \mathrm{C}$ & Time, $\mathrm{h}$ \\
\hline 600 & $0.16,0.5,1,4,16$ \\
650 & $0.16,0.5,2,8$ \\
800 & $0.05,0.16$ \\
\hline
\end{tabular}

A visual picture of some of these carbides can be seen from the study carried out to understand the evolution of microstructure in the early stages of tempering in a bid to establish carbide stability diagram for $10 \mathrm{CrMoV}$ steel. The starting material was in quenched condition. The heat treatment given to the test piece was as listed in Table 7.

The result of series of micrographs examined, after a given time, using TEM of samples held at $600^{\circ} \mathrm{C}$ is as shown in Figure 10.

In Figure 10(a), analysis shows that the small needleshaped particles are $M_{2} X$ precipitated along with $M_{3} C$.
After 30 minutes, the $\mathrm{M}_{2} \mathrm{X}$ precipitate intensified, while the $\mathrm{M}_{3} \mathrm{C}$ volume fraction remained approximately constant (Figure 10(b)). After 1 hour, there were additional blocky precipitates seen which were identified as $\mathrm{M}_{23} \mathrm{C}_{6} ; \mathrm{M}_{3} \mathrm{C}$ was present as well as $\mathrm{M}_{2} \mathrm{X}$ (Figure $10(\mathrm{c})$ ). Finally, after 16 hours, the microstructure consisted of relatively large $\mathrm{M}_{23} \mathrm{C}_{6}$ particles localized to lath boundaries along with $\mathrm{M}_{2} \mathrm{X}$ occurring within the laths (Figure 10(d)). follows:

The sequence observed in this test was summarized as

$$
\begin{aligned}
\mathrm{M}_{3} \mathrm{C}+\mathrm{M}_{2} \mathrm{X} & \longrightarrow \mathrm{M}_{3} \mathrm{C}+\mathrm{M}_{2} \mathrm{X}+\mathrm{M}_{23} \mathrm{C}_{6} \\
& \longrightarrow \mathrm{M}_{2} \mathrm{X}+\mathrm{M}_{23} \mathrm{C}_{6}
\end{aligned}
$$

It was reported that some fine MX phase could be present, although none was said to be found in this particular investigation. The same sequence was reported for test at $650^{\circ} \mathrm{C}$, but the precipitation kinetics was faster for all phases at this temperature.

At $800^{\circ} \mathrm{C}, \mathrm{M}_{23} \mathrm{C}_{6}$ was observed after only $3 \mathrm{~min}$, by which time $\mathrm{M}_{3} \mathrm{C}$ had dissolved. The approximate carbide 
stability diagram of this experiment can be found in these publications $[26,45]$. At $600^{\circ} \mathrm{C}$, the equilibrium precipitate for the 2.25Cr1Mo steel is $\mathrm{M}_{23} \mathrm{C}_{6}$, while for the $10 \mathrm{CrMoV}$ steel the equilibrium precipitates are $\mathrm{M}_{23} \mathrm{C}_{6}$ and $\mathrm{M}_{2} \mathrm{X}$. [7].

A common observation reported here is that once a metastable phase has completed precipitating (or enriching), it will start to dissolve to provide solute for all the more stable phases whose extent of reaction is less. So, in the case of the $10 \mathrm{CrMoV}$ steel, $\mathrm{M}_{3} \mathrm{C}$ and Laves phase eventually dissolve to provide solute to $\mathrm{M}_{2} \mathrm{X}$ and $\mathrm{M}_{23} \mathrm{C}_{6}$ which are the stable phases.

For the $10 \mathrm{CrMoV}$ steel, the order of events is first the rapid completion of $\mathrm{M}_{3} \mathrm{C}$ enrichment as the steel has a very large $\mathrm{Cr}$ concentration. This is followed by the completion of Laves precipitation; for this particular temperature $\left(600^{\circ} \mathrm{C}\right)$, Laves phase is a metastable (brittle) phase. It has been explained that because the precipitation of Laves phase is extremely sluggish, at the time it stops precipitating $(\sim 30 \mathrm{~min})$, the volume fraction which has formed is very small $\left(\sim 2 \times 10^{-9}\right)$. After this time, it dissolves rapidly and so is not experimentally observed. Finally, $\mathrm{M}_{2} \mathrm{X}$ and $\mathrm{M}_{23} \mathrm{C}_{6}$ form as the equilibrium phases.

This order of precipitation and enrichment is also observed in 2.25Cr1Mo steel but, due to low $\mathrm{Cr}$ concentration and higher $\mathrm{C}$ content in this steel, it is reported that $M_{2} C$ precipitation occurs and is finished well before $M_{23} C_{6}$ precipitation and the volume fractions of $\mathrm{M}_{2} \mathrm{C}$ and $\mathrm{M}_{3} \mathrm{C}$ are greater. Therefore, precipitation or enrichment of these phases removes a greater proportion of the available solute for the matrix than is removed in the $10 \mathrm{CrMoV}$ steel. The reduction in the solute available for $\mathrm{M}_{23} \mathrm{C}_{6}$ suppresses its formation to later times [7].

\section{Effect of Alloying Elements of Creep Steel on Phase Stability}

The large number of alloying elements in creep steel produces a huge variety of microstructure where the matrix can differ as well as the composition. The composition influences the phases' precipitation sequences and distribution.

The elements that make the composition of these steels have specific functions, even though there may be interaction among them. Increasing or decreasing their amount in search of better creep steel hinges on the understanding of their specific roles in the alloy system. These elements are usually

C, Mn, Ni, Co, Bo, Cu, Cr, Si, W, V, Mo, Ti, Nb, Ta (and $\mathrm{Nd}$ ), $\mathrm{Al}$, and $\mathrm{N}$.

Elements such as $\mathrm{Mn}, \mathrm{Mo}, \mathrm{Cr}, \mathrm{V}, \mathrm{W}, \mathrm{Ti}$, and $\mathrm{Nb}$ can both form stable carbides and be found in solid solution within the ferrite [26]. The studies on power steels show that Cr, W, and Mo provide solid solution strengthening. The precipitates that commonly form in this alloy system include $\mathrm{M}_{23} \mathrm{C}_{6}$, as well as MX (VN and $\mathrm{NbC}$ ). The drop in the strengthening effect of precipitate hardening is due to the coarsening of these precipitates [6].

The carbon content of the steel determines the amount of carbon in the carbide and the excess remains in solid solution in ferrite. Nitrogen is reported to enter the carbide phase, readily forming carbonitrides with iron and many alloying elements, and separate alloy nitride phases in the presence of Ti or Al [26].

The known characteristics of some of the elements are as follows.

Carbon (C). Carbon stabilizes austenite relative to ferrite. It is essential for the formation of carbides which cause the secondary hardening of power plant steels. It usually has peak value because high levels of carbon lead to unacceptable reductions in mechanical properties such as toughness and may cause cracking after normalization and also after welding. These effects have been studied by $[38,45,56]$.

Manganese $(\mathrm{Mn})$. Manganese stabilizes austenite but is often found to have an adverse effect on the creep strength of power plant steel. This phenomenon was attributed to the retention of austenite which will be rich in carbon and nitrogen, so reducing the effects of secondary hardening. Study shows that increasing $\mathrm{Mn}$ content may increase the growth rate of $\mathrm{M}_{6} \mathrm{X}$, an undesirable and coarse phase which can remove $\mathrm{W}$ from solid solution and cause the dissolution of other more desirable precipitates [57].

Nickel (Ni). Nickel stabilizes austenite and is found to accelerate the precipitation and coarsening of carbide phase and Laves phase. This coarsening reduces the creep properties and so is detrimental to creep properties of power plant alloys. $\mathrm{Ni}$ concentrations greater than $0.4 \mathrm{wt} \%$ have been shown to deteriorate the creep strength of high chromium steel appreciably [54]. This is because $\mathrm{Ni}$ increased the rate of dissolution of $\mathrm{M}_{2} \mathrm{X}$ as a consequence of precipitation of $\mathrm{M}_{6} \mathrm{X}$ phase. It increases the coarsening rate of $M_{6} X$ and $M_{23} C_{6}$ [54].

In the search for a creep-resistant steel capable of functioning at temperatures of $650-750^{\circ} \mathrm{C}$, in a very recent study, $15 \mathrm{Cr} 1 \mathrm{Mo}$ ferritic steel was alloyed with increasing Ni content as shown in Table 8.

The result of that endeavour is shown in Figure 11.

15Cr1Mo steel gave ferritic and martensitic phases upon quenching, with volume fraction of martensite increasing with $\mathrm{Ni}$ addition. The precipitates observed were reported to be Laves phase and $\chi$-phase (which are intermetallic compounds), $\mathrm{Cr}_{23} \mathrm{C}_{6}$ (chromium carbide), and Z-phase $(\mathrm{Cr}(\mathrm{V}$, $\mathrm{Nb}) \mathrm{N})[8,31]$. Ni was seen to cause preferential precipitation of $\mathrm{Cr}_{23} \mathrm{C}_{6}$ at grain boundaries between the ferrite and martensite. Once again $\mathrm{Ni}$ is seen to accelerate the precipitation of Laves phase. This study seems to show that at $650^{\circ} \mathrm{C}$ no effect in creep strength is seen by increasing Ni content of $15 \mathrm{Cr} 1 \mathrm{Mo}$ steel but there was huge creep strength improvement in comparison with T92 creep steel, whose composition is given as $9 \mathrm{Cr}-0.5 \mathrm{Mo}-1.8 \mathrm{~W}-\mathrm{V}-\mathrm{Nb}$, at each temperature. This huge difference is said to be due to increased precipitation of Lave phase and chromium carbide. The coarsening effect of $\mathrm{Ni}$ on carbide and Lave phases was not reported.

Cobalt (Co). Cobalt is austenite stabilizer and is found not to coarsen the steel microstructure like $\mathrm{Mn}$ and Ni. Study shows that cobalt strengthens the martensitic matrix and 
TABLE 8: 15CrlMo steel studied [8].

\begin{tabular}{lcccccccccc}
\hline & $\mathrm{C}$ & $\mathrm{Cr}$ & $\mathrm{Ni}$ & $\mathrm{Co}$ & $\mathrm{Mo}$ & $\mathrm{W}$ & $\mathrm{V}$ & $\mathrm{Nb}$ & $\mathrm{N}$ & $\mathrm{B}$ \\
\hline $0.8 \mathrm{Ni}$ & 0.051 & 15.16 & 0.86 & 1.96 & 1.03 & 6.03 & 0.21 & 0.06 & 0.037 & 0.0031 \\
$1.4 \mathrm{Ni}$ & 0.048 & 15.13 & 1.41 & 1.99 & 1.03 & 6.02 & 0.21 & 0.058 & 0.037 & 0.0031 \\
$2.1 \mathrm{Ni}$ & 0.051 & 15.07 & 2.15 & 2.04 & 0.98 & 6.03 & 0.21 & 0.054 & 0.036 & 0.0031 \\
\hline
\end{tabular}
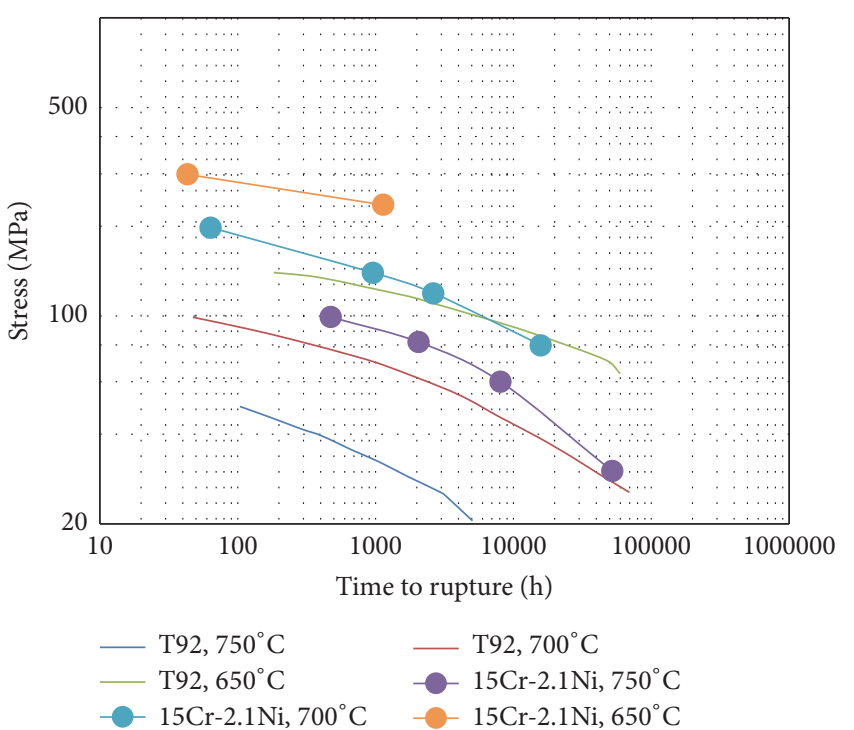

FIGURE 11: Comparison of stress versus creep rupture strength of $15 \mathrm{Cr}$ steels with increasing $\mathrm{Ni}$ content and $\mathrm{T} 92$ at $650-750^{\circ} \mathrm{C}$, adapted from [8]; also see [17].

enhances the stability of fine precipitates such as MX and $\mu$-phase. Cobalt was found to remain in solid solution in $12 \% \mathrm{Cr}$ steels, even with concentrations of up to $10 \mathrm{wt} \%$. This is beneficial effect for the creep rupture strength of creep steels. Irvine et al. (1960) [38] and Igarashi and Swaragi (1997) [58] have studied this beneficial effect. It is thought that cobalt promotes the formation of a stable oxide layer. However, the effects of cobalt additions on oxidation resistance are not well known. Major disadvantage in the use of Co as alloying element is that it makes steel difficult to recycle. In other words, cobalt-containing steels have a very low scrap value. In recent study, additions of $\mathrm{Co}$ and $\mathrm{Ni}$ were observed to strongly influence the creep strength and precipitation behaviour of intermetallic compounds (Laves phase, $\chi$-phase, and $\mu$-phase) during creep exposure at high temperature for 15Cr1Mo6W steel [31]. They found that creep strength is increased by precipitation of fine particles and homogenous dispersion of intermetallic particles in the ferritic matrix.

Boron. Study on boron additions shows beneficial effect on high temperature strength of $10 \mathrm{Cr}$ steel. It is found that longterm creep rupture strength was improved by B additions up to approximately $0.01 \mathrm{wt} \%$. This increase in rupture strength by boron has been attributed to stabilization of $\mathrm{M}_{23} \mathrm{C}_{6}$ at the grain boundaries, retardation of the coarsening of the precipitate, prevention of grain boundary sliding, and thereby dynamic recrystallization. Some research work on this can be found in $[14,57,59,60]$.

However, there appears to be no benefit to creep rupture properties at higher boron percentages. In fact, excessive boron is detrimental to strength due to the formation of undissolved boride phases [45]. Increased levels of boron are also found to lead to problems with weldability and forgeability. Excessive levels of boron can also combine with nitrogen to form quite coarse $\mathrm{BN}$ precipitates. This is seen to reduce the amount of finer nitrides in the alloy such as $\mathrm{VN}$, which can have beneficial effects on creep rupture properties, such as ductility [61].

Copper. Copper is an austenite stabilizing elements and is often added purely to counteract the undesirable formation of $\delta$-ferrite. Hence, copper is often used as an addition to power plant steels to retard $\delta$-ferrite formation, since it stabilizes the austenite phase. High copper additions, up to $2 \mathrm{wt} \%$, have been found to cause the precipitation of fine $\mathrm{Cu}$ particles on martensite lath boundaries which pins them and retarding the recovery of the martensite. It was also reported that $\mathrm{Cu}$ additions caused refinement of the prior austenite grain size. One concern with large copper additions is that it may precipitate and become removed from the alloy during heat treatment. Studies in this area have been reported by $[18,53$, 62].

Chromium. Chromium stabilizes ferrite and is carbide former. The addition of chromium to ferritic steels has been shown to improve the oxidation resistance. The high $\mathrm{Cr}$ steels are extremely corrosion-resistant but the lower $\mathrm{Cr}$ steels are susceptible to corrosion [6]. Studies have long established that $\mathrm{Cr}$ improves the steam oxidation resistance of ferrous alloys $[63,64]$. Large chromium additions of 9-10 wt $\%$ provide hardenability, good creep strength, and resistance to corrosion. An increase of $11 \mathrm{wt} \% \mathrm{Cr}$ was found to markedly increase corrosion resistance at creep steel at $650^{\circ} \mathrm{C}$; hence at least $11 \mathrm{wt} \% \mathrm{Cr}$ has been recommended in the design of a steel for use at $650^{\circ} \mathrm{C}$. Disadvantage of high concentrations of $\mathrm{Cr}$ is the promotion of undesirable $\delta$-ferrite formation. Ennis et al. (1998) [65] and Abe and Nakazawa (1992) [5] have reported this study.

Silicon. Silicon is a ferrite stabilizer and it is found to influence the rate at which carbide precipitates. It is also found to accelerate the precipitation and coarsening of Laves phase in $9 \mathrm{Cr}$ steels. Silicon additions, like $\mathrm{Cr}$, promote the formation of undesirable $\delta$-ferrite phase [66]. However, silicon can be very important in the formation of protective oxidation layers. It was reported that about $0.8 \mathrm{wt} \% \mathrm{Si}$ is required to form a protective layer at $650^{\circ} \mathrm{C}$ for $9 \mathrm{wt} \% \mathrm{Cr}$ steels, while $0.4 \mathrm{wt} \% \mathrm{Si}$ 


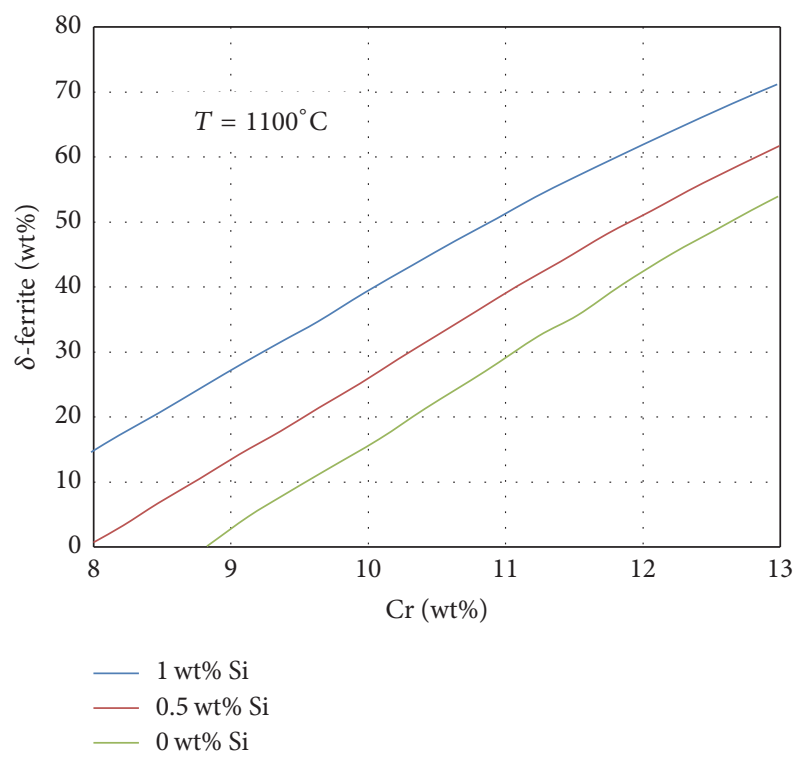

FIGURE 12: $\delta$-ferrite volume fraction as a function of $\mathrm{Cr}$ wt $\%$ for a steel of composition $0.08 \mathrm{C}-0 / 1 \mathrm{Si}-0.5 \mathrm{Mn} 8 / 13 \mathrm{Cr}-3 \mathrm{~W}-0.2 \mathrm{~V}-0.005 \mathrm{~B}-$ $0.005 \mathrm{~N}$ wt $\%$ [18].

is needed in the case of $12 \mathrm{wt} \% \mathrm{Cr}$ steels [6]. However, there is optimum silicon content of approximately $0.3 \mathrm{wt} \% \mathrm{Si}$ to give acceptable corrosion resistance and mechanical strength since it causes acceleration of Laves phase precipitation and coarsening. Study has shown that silicon content above $0.4 \mathrm{wt} \%$ leads to deterioration in tensile strength, creep rupture strength, and toughness due to $\delta$-ferrite formation. Therefore, the formation of $\delta$-ferrite has been the major problem with silicon additions [18].

Figure 12 shows calculation using Thermo-Calc for a model steel, comparing the amount of $\delta$-ferrite which forms during austenitization with $\mathrm{Cr}$ and $\mathrm{Si}$ content.

The figure clearly shows that the addition of high $\mathrm{Cr}$ or $\mathrm{Si}$ content will cause $\delta$-ferrite formation during austenitization around $1100^{\circ} \mathrm{C}$. To mitigate against this, austenite stabilizing element is commonly added. These characteristics are balanced with the effect on the mechanical properties when designing ferritic alloys with significant silicon contents. Other reports on Si study can be found in $[41,66,67]$.

Tungsten. Tungsten is a ferrite stabilizer and strong carbide former. It has been found to stabilize $\mathrm{M}_{2} \mathrm{X}$ though less effective. Tungsten promotes the formation of Laves phase. Like $\mathrm{Cr}$ and $\mathrm{Si}$, high contents of tungsten may lead to the formation of undesirable $\delta$-ferrite [45].

In general, tungsten addition has been found to improve the creep rupture strength of ferritic heat-resistant steels. This effect was attributed to solid solution hardening and precipitation strengthening due to $\mathrm{M}_{23} \mathrm{C}_{6}$ and Laves phase. $\mathrm{M}_{23} \mathrm{C}_{6}$ and Laves phase were found to precipitate at grain boundaries and this is believed to be the main factor responsible for the improved creep rupture strength. Study shows that increased $\mathrm{W}$ concentrations in a $9 \mathrm{Cr}$ alloy reduced the coarsening rate of $\mathrm{M}_{23} \mathrm{C}_{6}$ precipitates. In turn, this reduced the coarsening of martensite laths due to the pining effects of $\mathrm{M}_{23} \mathrm{C}_{6}$, thus delaying recovery. Report also has it that the coarsening rate of Laves phase was very large in these alloys. Reports on effects of tungsten addition to creep steel can be found readily in $[29,46,68]$.

Vanadium. Vanadium is a ferrite stabilizer and strong carbide former. Vanadium is a key element due to the stability of its nitride, and this nitride is found to improve the creep rupture strength of steel. Like $\mathrm{W}$, it stabilizes $\mathrm{M}_{2} \mathrm{X}$ phase and also MX. Vanadium additions to $10-12 \mathrm{wt} \% \mathrm{Cr}$ steels have been found to significantly improve the long-term creep strength. The strengthening effect of vanadium may also be enhanced by the removal of available carbon into vanadium carbides, thus leaving Mo in the matrix, where it contributes to solid solution strengthening. Reports on this study can be found in $[6,69-72]$.

Molybdenum. Molybdenum forms stable carbides and remains in ferrite, contributing to solid solution strengthening. Like $\mathrm{W}$ and Va, Mo has been shown to stabilize $\mathrm{M}_{2} \mathrm{X}$ phase and a phase given as $\mathrm{M}_{3} \mathrm{C}_{6}$ phase. Increasing $\mathrm{Mo}$ concentration above $1 \mathrm{wt} \%$ has been found to promote formation of $\mathrm{M}_{6} \mathrm{C}$, Laves phase, and $\delta$-ferrite in $9 \mathrm{wt} \% \mathrm{Cr}$ steels. Study in this area can be found in $[69,71,73]$.

Titanium. Titanium is strong carbide and nitride former and improves the creep rupture strength of ferritic steels. However, increase in Ti may result in a large reduction in rupture ductility due to $\mathrm{Ti}$ based inclusions preventing deformation at grain boundaries.

Niobium. Niobium addition is found to give MX carbides and nitrides which are small and stable. These precipitates help to pin grain boundaries and prevent grain growth. The effectiveness of this mechanism relies on dissolving $\mathrm{Nb}$ during austenitization; otherwise insoluble NbC remains, causing coalescence of the precipitates, coarsening them, and accelerating recovery. Increased level of $\mathrm{Nb}$ may also cause the formation of undesirable Z-phase. Further information on this can be found in [69].

Tantalum (and Neodymium). The additions of $\mathrm{Ta}$ and $\mathrm{Nd}$ to creep steel have been found to be beneficial to the creep rupture strength of weld joints in a $0.1 \mathrm{C}-11 \mathrm{Cr}-3 \mathrm{~W}-3 \mathrm{Co}-\mathrm{V}-$ $\mathrm{Nb}-\mathrm{N}$ steel. Igarashi and Swaragi (1997) [58] reported that this effect was attributed to the formation of $\mathrm{TaN}$ and $\mathrm{NdN}$ precipitates. These nitrides were found to be extremely stable and do not coarsen appreciably during welding and the subsequent heat treatment.

Aluminum. The addition of $\mathrm{Al}$ is thought to be detrimental to the creep rupture strength, since it leads to the formation of AlN instead of VN or NbN. AlN is a coarse phase and not useful to creep strength, while the others are fine and dispersed and so improve creep property.

Nitrogen. Nitrogen, like carbon, is small enough to occupy interstitial sites in the iron lattice and stabilizes austenite relative to ferrite. It has been found to stabilize MX precipitate 
in $\mathrm{Cr}$ steels, probably of the composition $\mathrm{CrN}$, and this has been one of the reasons suggested why $\mathrm{N}$ additions may increase creep strength [38]. Nitrogen addition is found to aid the formation of MX type precipitate, such as VN and $\mathrm{NbN}$, which are fine and generally desirable for creep strength. Potential disadvantage militating against full utilization of nitrogen is said to be the difficulty associated with increasing nitrogen content of ferritic steels above approximately $0.08 \mathrm{wt} \%$ without pressurizing the cast in a nitrogen atmosphere. This adds to the cost of designing.

However, study shows that addition of nitrogen to boron containing steels may precipitate $\mathrm{BN}$ which can offset the beneficial effects of both $B$ and N. Report on effect of nitrogen on creep steel can also be found in $[38,61,74]$.

Phosphorus. The presence of phosphorus in substantial amount is found to lead to segregation to grain boundaries which embrittles the alloy. Study shows that it reduces the volume fraction of beneficial $\mathrm{M}_{2} \mathrm{X}$ precipitates and increases creep rate. Phosphorus is said to interact and drive the segregation of Mo at prior austenite grain boundaries and results in loss of ductility in 9Cr1Mo steel. Pilling et al. (1982) [70] and Noble et al. (1990) [75] have some report on the effect of this element on creep steel.

Sulphur. Formation of sulphides, such as MnS, can provide preferential nucleation sites for cavitation. Precipitation occurs on prior austenite grain boundaries when cooling from the austenite. The cavitation is caused by the low interfacial adhesion between $\mathrm{MnS}$ and the ferrite matrix [44].

It is usually useful to examine the combined effect of elements that behave in a similar manner rather than individual effects. For example, $\delta$-ferrite promoters are $\mathrm{Cr}$, $\mathrm{Si}$, $\mathrm{W}$, and Mo. For the effect of $\mathrm{W}$ and Mo concentrations on 9 Cr alloys, it is found that, in the range $0.5>$ Mo wt $\%>0.8$, Mo improved the creep rupture strength [76]. This is just one example of the many interactions between variables which make alloy design extremely difficult.

From above discussions one can see that the elements that make up the creep steel composition are added for a variety of reasons. The carbide formers are $\mathrm{Ti}, \mathrm{W}, \mathrm{Va}, \mathrm{Cr}, \mathrm{Nb}$, $\mathrm{Mo}, \mathrm{Si}$ and the undesirable $\delta$-ferrite promoters tend to be ferrite stabilizers, like Si, Mo, Cr, W, V. and the counteracting elements the austenite stabilizers, that is, $\mathrm{C}, \mathrm{Mn}, \mathrm{Ni}, \mathrm{Co}, \mathrm{Cu}$ and $\mathrm{N}$.

\section{Conclusion}

We can see that power plant steels are designed by considering the known effects of each single element and their interactions. This interaction makes the design of this class of steel extremely challenging venture. These elements are added either to stabilize phases which are beneficial to creep resistance or to suppress phases which are detrimental. The nature of steel has created opportunity to design steels that have served man in the high temperature domain, up to $650^{\circ} \mathrm{C}$ for decades. There are emerging possibilities of alloying with nickel and boron to produce steel that functions at $700^{\circ} \mathrm{C}$ and above, where the alloys are independent of any carbides as strengthening factors. The current studies on $15 \mathrm{Cr}$ steel are keeping the hope alive. The success of this is expected to increase tremendously the efficiency of power plants by $50 \%$ and the concomitant reduction in the emissions of gases such as $\mathrm{CO}_{2}, \mathrm{NO}_{x}$, and $\mathrm{SO}_{x}$. The immense possibility of altering steel microstructure to create wide ranges of mechanical properties underscores the critical role that steel has played in the construction of our society. It just appears that the potential of steel is limitless.

\section{Competing Interests}

The authors declare that there are no competing interests regarding the publication of this paper.

\section{Acknowledgments}

The authors are grateful to HKDH Bhadeshia of University of Cambridge for his numerous insightful and inspiring papers and his willingness to be open in information dissemination in phase transformation study. They relied heavily on his research activities. They also wish to commend David Graham Cole whose Ph.D. thesis is a mine of information. His work aided in no small measure in this review.

\section{References}

[1] J. Chen, Modelling of simultaneous transformations in steels [Ph.D. thesis], Department of Materials Science and Metallurgy, Fitzwilliam College, University of Cambridge, 2009.

[2] H. K. D. H. Bhadeshia, "Novel aspects of ferritic steels for the generation of electricity," in Proceedings of the 4th International Symposium on Mechanical Science based on Nanotechnology, pp. 143-146, Sendai, Japan, 2007.

[3] M. Murugananth and H. K. D. H. Bhadeshia, "Components of the creep strength of welds," in Mathematical Modelling of Weld Phenomena-VI, H. Cerjak and H. K. D. H. Bhadeshia, Eds., pp. 243-260, Institute of Materials, 2002.

[4] H. K. D. H. Bhadeshia, A. Strang, and D. J. Gooch, "Ferritic power plant steels: remanent life assessment and approach to equilibrium," International Materials Reviews, vol. 43, no. 2, pp. 45-69, 1998.

[5] F. Abe and S. Nakazawa, "Microstructural evolution and creep behaviour of bainitic, martensitic, and martensite-ferrite dual phase Cr-2W steels," Materials Science and Technology, vol. 8, no. 12, pp. 1063-1069, 1992.

[6] D. G. Cole, Designs of heat-resistant steels for small power plant [Ph.D. thesis], Materials Science and Metallurgy, Darwin College, University of Cambridge, 2000.

[7] J. D. Robson and H. K. D. H. Bhadeshia, "Modelling precipitation sequences in powerplant steels Part 2-application of kinetic theory," Materials Science and Technology, vol. 13, no. 8, pp. 640-644, 1997.

[8] M. Shibuya, Y. Toda, K. Sawada, H. Kushima, and K. Kimura, "Improving the high-temperature creep strength of $15 \mathrm{Cr}$ ferritic creep-resistant steels at temperatures of 923-1023 K," Materials Science and Engineering A, vol. 652, pp. 1-6, 2016.

[9] H. K. D. H. Bhadeshia, "Estimation of the microstructure and properties of ferritic creep-resistant steels," in Modelling of Microstructural Evolution in Creep Resistant Materials, A. Strang 
and M. McLean, Eds., pp. 15-38, The Institute of Materials, London, UK, 1999.

[10] H. K. D. H. Bhadeshia, "Thermodynamic analysis of isothermal transformation diagrams," Metal Science, vol. 16, no. 3, pp. 159$165,1982$.

[11] F. Brun, T. Yoshida, J. D. Robson, V. Narayan, H. K. D. H. Bhadeshia, and D. J. C. MacKay, "Theoretical design of ferritic creep resistant steels using neural network, kinetic, and thermodynamic models," Materials Science and Technology, vol. 15 , no. 5 , pp. 547-554, 1999.

[12] D. Cole, C. Martin-Moran, A. G. Sheard, H. K. D. H. Bhadeshia, and D. J. C. MacKay, "Modelling creep rupture strength of ferritic steel welds," Science and Technology of Welding and Joining, vol. 5, no. 2, pp. 81-89, 2000.

[13] F. Abe, "Coarsening behaviour of martensite lathes in tempered martensitic 9Cr-W steels during creep deformation," in Proceedings of the 4th International Conference on Recrystallization and Related Phenomena, pp. 289-294, The Japan Institute of Metals, 1999.

[14] F. Abe, "Research and development of advanced ferritic steel for $650^{\circ} \mathrm{C}$ USC boilers," in Proceedings of the at 4th UltraSteels Workshop that took place in 2000 at Tsukuba International Congress CenterTitle: Ultra-Steel 2000: Innovative Structural Materials for Infrastructure in 21st Century Sponsor, pp. 119-129, National Research Institute for Metals, Tsukuba, Japan, 2000.

[15] H. K. D. H. Bhadeshia, "Design of ferritic creep-resistant steels," ISIJ International, vol. 41, no. 6, pp. 626-640, 2001.

[16] F. Abe, High Performance Creep Resistant Steels for 21st Century Power Plants, National Institute for Materials Science (NIM), Tsukuba, Japan, 1999.

[17] M. Shibuya, Y. Toda, K. Sawada, H. Kushima, and K. Kimura, "Effect of precipitation behavior on creep strength of $15 \% \mathrm{Cr}$ ferritic steels at high temperature between 923 and $1023 \mathrm{~K}$," Materials Science and Engineering A, vol. 592, pp. 1-5, 2014.

[18] F. Abe, M. Igarashi, N. Fujitsuna, and K. Kimura, "Research and development of advanced ferritic steels for $650^{\circ} \mathrm{C}$ USC boilers," in Proceedings of the 6th Liege Conference in Materials for Advanced Power Engineering, vol. 5, part 1, pp. 259-268, 1998.

[19] F. Kauffmann, T. Klein, A. Klenk, and K. Maile, "Creep behavior and in-depth microstructural characterization of dissimilar joints," Science and Technology of Advanced Materials, vol. 14, no. 1, Article ID 014203, 2013.

[20] H. K. D. H. Bhadeshia, "Creep-resistant steel-case study", in Kinetics and Microstructure Modelling Lecture Note for Course MP6, pp. 1-6, Department of Materials \& Metallurgy University of Cambridge, 2013.

[21] R. Viswanathan, J. F. Henry, J. Tanzosh, G. Stanko, J. Shingledecker, and B. Vitalis, "Materials for ultrasupercritical coal fired power plant boilers," in Proceedings of the 29th International Technical Conference on Coal Utilization and Fuel Systems, Clearwater, Fla, USA, 2004.

[22] A. Helmrich, Q. Chen, G. Stamatelopoulos, and B. Scarlin, "Materials development for advanced steam boilers," in Proceedings of the 8th Liege Conference on Materials for Advanced Power Engineering, J. Lecomte-Beckers, M. Carton, F. Schubert, and P. J. Ennis, Eds., vol. 2, pp. 931-948, September 2006.

[23] W. D. Callister, Materials Science and Engineering: An Introduction, John Wiley \& Sons, New York, NY, USA, 7th edition, 2007.

[24] J. Rösler, H. Harders, and M. Baeker, Mechanical Behaviour of Engineering Materials: Metals, Ceramics, Polymers, and Composites, Springer, Berlin, Germany, 2007.
[25] H. K. D. H. Bhadeshia, Bainite in Steels: Transformations, Microstructure and Properties, The Institute of Materials, London, UK, 2nd edition, 2001.

[26] R. C. Thomson, Carbide composition changes in power plant steels as a method of remanent creep life prediction [Ph.D. thesis], Department of Materials Science and Metallurgy, Newnham College, University of Cambridge, 1992.

[27] F. Masuyama and T. Yokoyama, "High temperature materials for power engineering," in Materials for Advanced Power Engineering, D. Coutsouradis, J. H. Davidson, J. Ewald et al., Eds., pp. 301-308, Kluwer Academic, Dordrecht, The Netherlands, 1994.

[28] K. Kimura, H. Kushima, F. Abe, K. Yagi, and H. Iries, "Assessment of creep strength properties of 9-12\%Cr steels," in Advances in Turbine Materials, Design and Manufacturing, 4th International Charles Parsons Turbine Conference, pp. 257-269, The Institute of Materials, London, UK, 1997.

[29] H. K. D. H. Bhadeshia, Mechanical Properties of Martensite in Heat-resistant Steels, Proceedings of Ultra-Steel 2000, National Research Institute for Metals, Tsukuba, Japan, 2000.

[30] K. Kimura, Y. Toda, H. Kushima, and K. Sawada, "Creep strength of high chromium steel with ferrite matrix," International Journal of Pressure Vessels and Piping, vol. 87, no. 6, pp. 282-288, 2010

[31] M. Shibuya, Y. Toda, K. Sawada, H. Kushima, and K. Kimura, "Effect of nickel and cobalt addition on the precipitationstrength of $15 \mathrm{Cr}$ ferritic steels," Materials Science and Engineering $A$, vol. 528, no. 16-17, pp. 5387-5393, 2011.

[32] J. D. Robson and H. K. D. H. Bhadeshia, "Modelling precipitation sequences in power plant steels part 1-Kinetic theory," Materials Science and Technology A, vol. 13, no. 8, pp. 631-639, 1997.

[33] Y. Murata, M. Morinaga, and R. Hashizume, "Development of ferritic steels for steam turbine rotors with the aid of a molecular orbital method," in Advances in Turbine Materials, Design and Manufacturing, 4th International Charles Parsons Turbine Conference, A. Strang, W. M. Banks, and R. D. Conroy, Eds., pp. 270-282, The Institute of Materials, London, UK, 1997.

[34] M. Morinaga, R. Hashizume, Y. Murata et al., "Electronic approach to the design of ferritic steels for power plants," in Materials for Advanced Power Engineering, D. Coutsouradis, J. H. Davidson, J. Ewald et al., Eds., part 1, pp. 319-328, Kluwer Academic, Dordrecht, The Netherlands, 1994.

[35] C. J. Tillman and D. V. Edmonds, "Alloy carbide precipitation and aging during high-temperature isothermal decomposition of an Fe-4Mo-0.2C alloy steel," Metals Technology, vol. 1, no. 10, pp. 456-461, 1974.

[36] V. K. Sikka, M. G. Cowgill, and B. W. Roberts, "Creep properties of modified 9Cr-1Mo steel," in Proceedings of the Topical Conference on Ferritic Alloys for Use in Nuclear Energy Technologies, pp. 412-423, TMS-AIME, Warrendale, Pa, USA, 1984.

[37] R. G. Baker and J. Nutting, "The tempering of 2.25Cr1Mo steel after quenching and normalizing," Journal of the Iron and Steel Institute, vol. 191, no. 3, pp. 257-268, 1959.

[38] K. J. Irvine and F. B. Pickering, "The temperature characteristics of low-carbon low-alloy steels," Journal of Iron and Steel Institute, vol. 194, no. 2, pp. 137-153, 1960.

[39] J. M. Titchmarsh, "The identification of second-phase particles in steels using an analytical transmission electron microscope," in Proceedings of the 9th International Conference on Electron Microscopy, J. M. Sturgess, Ed., vol. 1, pp. 618-619, Microscopical Society of Canada, Toronto, Canada, 1978. 
[40] J. Beech and D. H. Warrington, " $\mathrm{M}_{7} \mathrm{C}_{3}$ to $\mathrm{M}_{23} \mathrm{C}_{6}$ transformation in chromium containing alloys," Journal of the Iron and Steel Institute, vol. 204, no. 5, pp. 460-468, 1966.

[41] J. H. Woodhead and A. G. Quarrell, "Role of carbides in lowalloy creep resisting steels," Journal of the Iron and Steel Institute, vol. 203, pp. 605-620, 1965.

[42] F. Abe, "Bainitic and martensitic creep-resistant steels," Current Opinion in Solid State and Materials Science, vol. 8, no. 3-4, pp. 305-311, 2004.

[43] D. V. Edmonds and R. W. K. Honeycombe, "Structure and properties of an isothermally transformed Fe-4Mo-0.2C alloy," Journal of the Iron and Steel Institute, vol. 211, pp. 209-216, 1973.

[44] J. Nutting, "The structural stability of low alloy steels for power generation application," in Advanced Heat Resistant Steel for Power Generation, R. Viswanathan and J. Nutting, Eds., pp. 1230, Institute of Materials, Minerals and Mining, 1999.

[45] J. D. Robson, Modelling of carbide and Laves phase precipitation in 9-12wt\% chromium steels [Ph.D. thesis], Materials Science and Metallurgy, Clare College, University of Cambridge, 1996.

[46] M. Ohgami, H. Minura, and H. Naoi, "Creep rupture properties and microstructures of a new ferritic W containing steel," in Proceedings of the 5th International Conference on Creep of Materials, pp. 69-73, Lake Buena Vista, Fla, USA, 1992.

[47] B. K. Choudhary, "Tertiary creep behaviour of 9Cr-1Mo ferritic steel," Materials Science and Engineering A, vol. 585, pp. 1-9, 2013.

[48] A. Strang and V. Vodárek, "Z phase formation in martensitic 12CrMoVNb steel," Materials Science and Technology, vol. 12, no. 7, pp. 552-556, 1996.

[49] K. Sawada, K. Suzuki, H. Kushima, M. Tabuchi, and K. Kimura, "Effect of tempering temperature on Z-phase formation and creep strength in 9Cr-1Mo-V-Nb-N steel," Materials Science and Engineering A, vol. 480, no. 1-2, pp. 558-563, 2008.

[50] H. K. Danielsen and J. Hald, "On the nucleation and dissolution process of Z-phase $\mathrm{Cr}(\mathrm{V}, \mathrm{Nb}) \mathrm{N}$ in martensitic $12 \% \mathrm{Cr}$ steels," Materials Science and Engineering A, vol. 505, no. 1-2, pp. 169177, 2009.

[51] L. Cipolla, H. K. Danielsen, D. Venditti, P. E. Di Nunzio, J. Hald, and M. A. J. Somers, "Conversion of MX nitrides to Z-phase in a martensitic $12 \%$ Cr steel," Acta Materialia, vol. 58, no. 2, pp. 669-679, 2010.

[52] J. Pilling and N. Ridley, "Tempering of 2.25 Pct Cr-1 Pct Mo low carbon steels," Metallurgical Transactions A, vol. 13, no. 4, pp. 557-563, 1982.

[53] A. Iseda, Y. Sawaragi, S. Kato, and F. Masuyama, "Development of a new $0.1 \mathrm{C}-11 \mathrm{Cr}-2 \mathrm{~W}-0.4 \mathrm{Mo}-1 \mathrm{Cu}$ steel for large diameter and thick wall pipe for boilers," in Creep: Characterization, Damage and Life Assessments, Proceedings of the 5th International Conference on Creep of Materials, Lake Buena Vista, Florida, USA, ASM International, 1992.

[54] V. Vodárek and A. Strang, "Effect of nickel on the precipitation processes in $12 \mathrm{CrMoV}$ steels during creep at $550^{\circ} \mathrm{C}$," Scripta Materialia, vol. 38, no. 1, pp. 101-106, 1997.

[55] S. D. Mann, D. G. McCulloch, and B. C. Muddle, "Identification of $\mathrm{M}_{5} \mathrm{C}_{2}$ carbides in ex- service $1 \mathrm{Cr}-0.5 \mathrm{Mo}$ steels," Metallurgical and Materials Transactions A, vol. 26, article 509, 1995.

[56] T. Fujita and K. Asakura, "Effects of carbon on creep rupture strength and toughness of high $\mathrm{Cr}$-Mo heat-resisting steels containing $\mathrm{V}$ and Nb," Transactions of the Iron and Steel Institute of Japan, vol. 26, no. 12, pp. 1073-1079, 1986.
[57] K. Miyata, M. Igarashi, and Y. Sawaragi, "Effect of trace elements on creep properties of $0.06 \mathrm{C}-2.25 \mathrm{Cr}-1.6 \mathrm{~W}-0.1 \mathrm{Mo}-0.25 \mathrm{~V}-$ 0.05Nb steel," ISIJ International, vol. 39, no. 9, pp. 947-954, 1999.

[58] M. Igarashi and Y. Swaragi, "Development of 0.1C-11Cr-3W3Co-V-Nb-Ta-Nd-N ferritic steel for USC boilers," in Proceedings of the International Conference on Power Engineering, pp. 107-112, Japan Society of Mechanical Engineers (JSME), Tokyo, Japan, 1997.

[59] I. M. Park and T. Fujita, "Long-term creep rupture properties and microstructure of $12 \% \mathrm{Cr}$ heat resisting steels," Transactions of the Iron and Steel Institute of Japan, vol. 22, no. 11, pp. 830-837, 1982.

[60] M. Hättestrand and H.-O. Andrén, "Boron distribution in 9$12 \%$ chromium steels," Materials Science and Engineering A, vol. 270, no. 1, pp. 33-37, 1999.

[61] F. Abe, "Effect of boron on microstructure and creep strength ofadvanced ferritic power plant steels," Procedia Engineering, vol. 10, pp. 94-99, 2011.

[62] T. Tsuchiyama, Y. Futamura, and S. Takaki, "Strengthening of heat resistant martensitic steel by $\mathrm{Cu}$ addition," in Creep and Fracture of Engineering Materials and Structures, T. Sakuma and K. Yagi, Eds., vol. 171-174 of Key Engineering Materials, pp. 411418, 2000.

[63] H. L. Solberg, G. A. Hawkins, and A. A. Potter, "Corrosion of unstressed steel specimens by high temperature steam," Transactions of the American Society of Mechanical Engineers, vol. 64, pp. 303-316, 1942.

[64] I. A. Rohrig, R. M. Van Duzer, and C. H. Fellows, "High temperature steam corrosion studies at Detroit," Transactions of the American Society of Mechanical Engineers, vol. 66, pp. 277290, 1944.

[65] P. J. Ennis, Y. Wouters, and W. J. Quadakkers, "The effects of oxidation on the service life of 9-12 wt\% Cr steels," in Advanced Heat Resistant Steels for Power Generation, San Sabastian, Spain, R. Viswanathan and J. Nutting, Eds., pp. 457-467, IoM Communications, 1998.

[66] Y. Kato, M. Ito, Y. Kato, and O. Furukim, "Effect of Si on precipitation behaviour of $\mathrm{Nb}$-laves phase and amount of $\mathrm{Nb}$ in Solid solution at elevated temperature in high purity $17 \% \mathrm{Cr}-$ 0.5\%Nb Steels," Materials Transactions, vol. 51, no. 9, pp. 1531$1535,1986$.

[67] N. Fujitsuna, M. Igarashi, and G. R. Booker, "Acceleration of $\mathrm{Fe} 3 \mathrm{~W}$ precipitation and its effect on creep deformation behaviour of $8.5 \mathrm{Cr}-2 \mathrm{~W}$-VNb steels with $\mathrm{Si}$," in Creep and Fracture of Engineering Materials and Structures, T. Sakuma and K. Yagi, Eds., vol. 171-174 of Key Engineering Materials, pp. 469476, 2000.

[68] J. Vanaja, K. Laha, M. D. Mathew, T. Jayakumar, and E. Rajendra Kumar, "Effects of tungsten and tantalum on creep deformation and rupture properties of reduced activation ferriticmartensitic," Procedia Engineering, vol. 55, pp. 271-276, 2013.

[69] T. Fujita, K. Asakura, T. Sawada, T. Takamatsu, and Y. Otoguro, "Creep rupture strength and microstructure of low C-10Cr-2Mo heat-resisting steels with $\mathrm{V}$ and Nb," Metallurgical Transactions A, vol. 12, no. 6, pp. 1071-1079, 1981.

[70] J. Pilling and N. Ridley, "Tempering of 2.25 Pct Cr-1 Pct Mo Low Carbon Steels," Metallurgical Transactions A, vol. 13, no. 4, pp. 557-563, 1982.

[71] D. J. Gooch, "Creep fracture of $12 \mathrm{CrMoV}$ steel," Metal science, vol. 16, no. 2, pp. 79-89, 1982.

[72] T. Fujita and N. Takahashi, "The effects of V and Nb on the long period creep rupture strength of $12 \mathrm{wt} \% \mathrm{Cr}$ heat-resisting steel 
containing Mo and B," Transactions of the Iron and Steel Institute of Japan, vol. 18, pp. 269-278, 1979.

[73] V. Foldyna, A. Jakobova, R. Riman, and A. Gemperle, "Effect of structural factors on the creep properties of modified chromium steels," Steel Research, vol. 62, no. 10, pp. 453-458, 1991.

[74] F. Masuyama and M. Ohgami, "Creep behaviour of high nitrogen ferritic steel," in Proceedings of the 7th International Symposium on Aspects of High Temperature Deformation and Fracture in Crystalline Materials, Y. Hosoi, H. Yoshinaga, H. Oikawa, and K. Maruyama, Eds., pp. 325-332, Japan Institute of Metals, Sendai, Japan, 1993.

[75] F. W. Noble, B. A. Senior, and B. L. Eyre, "The effect of phosphorus on the ductility of 9Cr-1Mo steels," Acta Metallurgica et Materialia, vol. 38, no. 5, pp. 709-717, 1990.

[76] H. Naoi, M. Ohgami, Y. Hasegawa et al., "Mechanical properties of $12 \mathrm{Cr}-\mathrm{W}$-Co ferritic steels with high creep rupture strength," in Materials for Advanced Power Engineering', Part 1, D. Coutsouradis, J. J. Davidson, J. Ewald, and T. Fujita, Eds., vol. 1, pp. 425-434, Kluwer Academic, Dordrecht, The Netherlands, 1994. 

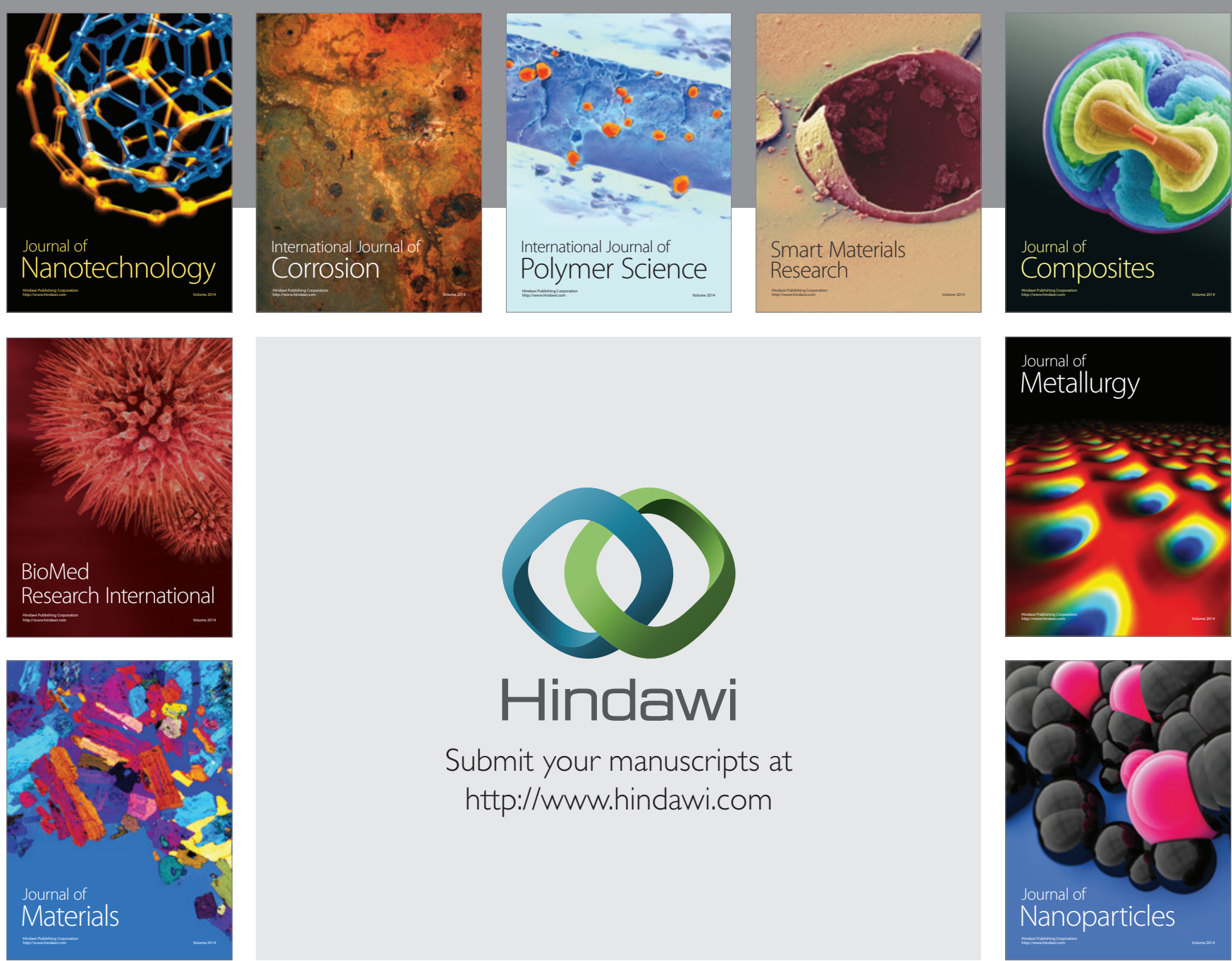

\section{Hindawi}

Submit your manuscripts at

http://www.hindawi.com

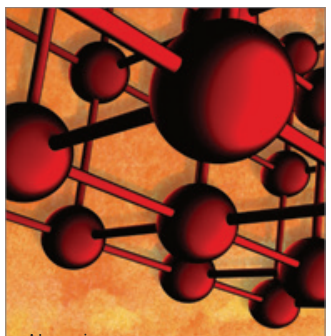

Materials Science and Engineering
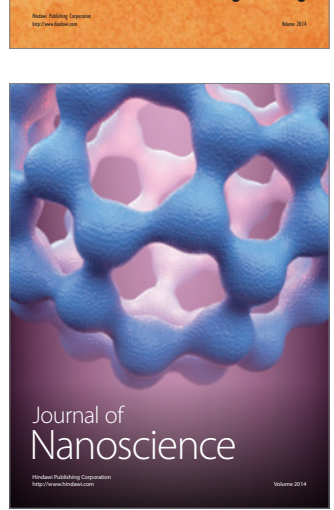
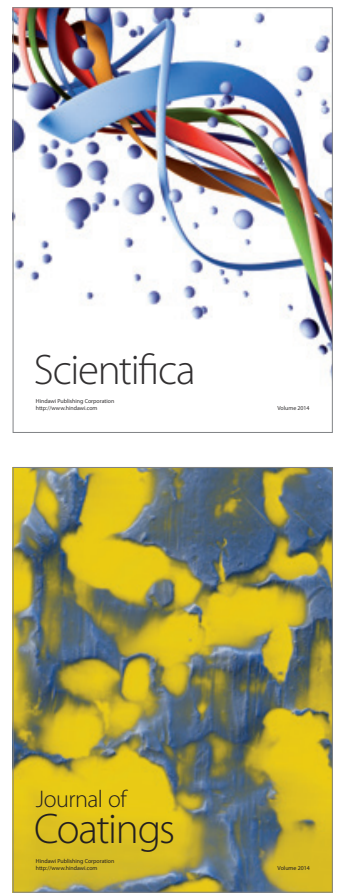
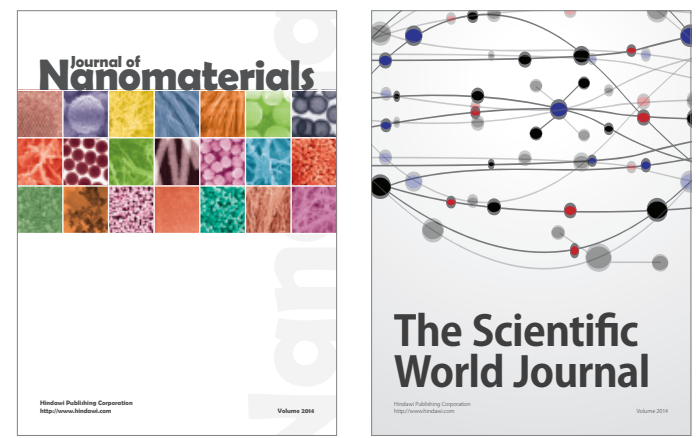

The Scientific World Journal
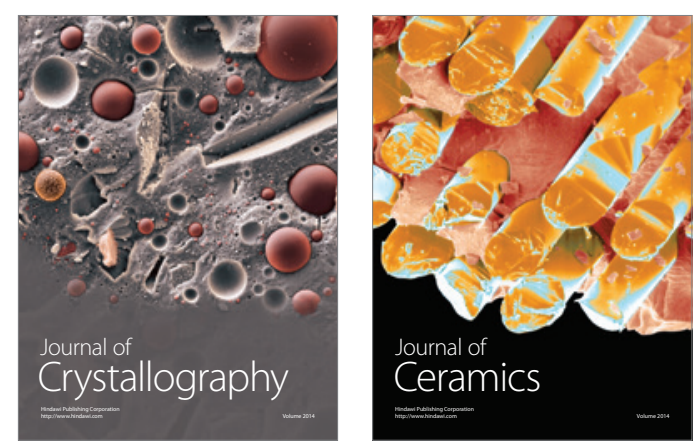
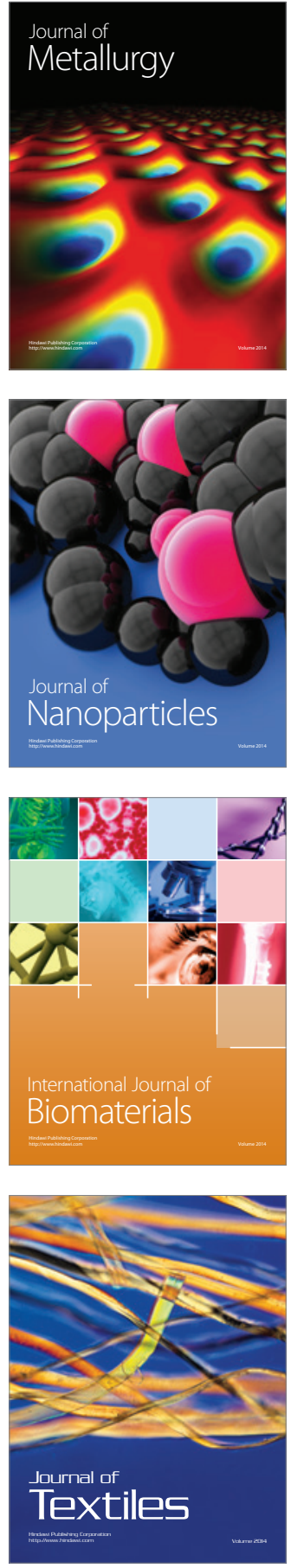